\title{
A biosynthesis view on nutrient stress in coastal phytoplankton
}

\author{
Julia Grosse, ${ }^{1 *}$ Peter van Breugel, ${ }^{2}$ Corina P. D. Brussaard, ${ }^{1}$ Henricus T. S. Boschker ${ }^{1 *}$ \\ ${ }^{1}$ Royal Netherlands Institute for Sea Research, Department of Marine Microbiology and Biogeochemistry, and Utrecht \\ University, Texel, The Netherlands \\ ${ }^{2}$ Royal Netherlands Institute for Sea Research, Department of Estuarine and Delta Systems, and Utrecht University, Yerseke, \\ The Netherlands
}

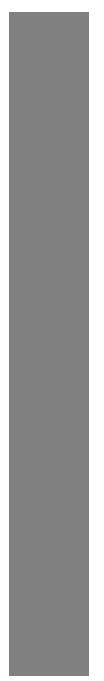

\begin{abstract}
Anthropogenic activities resulted in major shifts in nutrient inputs to coastal seas, which may have altered the biomolecule composition of phytoplankton because of different $\mathrm{C}: \mathrm{N}: \mathrm{P}$ requirements for biosynthesis. In order to understand the effects of $\mathrm{N}$ - and P-limitation on the allocation of photosynthetically fixed $\mathrm{C}$, we directly measured seasonal and spatial dynamics of amino acid, fatty acid and carbohydrate concentrations and biosynthesis rates in the phytoplankton of the North Sea using a novel ${ }^{13}$ C-tracer approach. Nutrient limitation and season had large effects on composition and biosynthesis rates of all biochemical classes, for instance the contribution of protein derived amino acids varied up to fourfold in concentration and up to eightfold in biosynthesis rates. Nutrient specific effects and the prevailing nutrient limitations were identified by short-term (24-72 h) nutrient addition experiments. Addition of the growth-limiting nutrient increased amino acid synthesis while storage compound synthesis decreased concurrently. The strongest effect was detected in N-limited flagellates, where amino acid synthesis increased up to fivefold within $24 \mathrm{~h}$ upon relief of nutrient limitation. P-limitation was only detected in diatom-dominated near-coast stations, and amino acid synthesis responded much slower, likely because of the necessary preceding synthesis of ribosomes. This metabolic elasticity of phytoplankton in response to nutrient availability will have major consequences for their nutritional value within the food web and subsequently the carrying capacity of coastal ecosystems.
\end{abstract}

Increases in riverine nutrient loadings, due to anthropogenic activities, led to eutrophication in coastal seas worldwide resulting in increased phytoplankton biomass (Cadée and Hegeman 2002), shifts in species composition (Philippart et al. 2000), formation of toxic algal blooms (Riegman et al. 1992; Lancelot et al. 2007) as well as changes in trophic food web structures (Van Beusekom and DielChristiansen 2009). In order to reduce these effects much effort was raised in recent decades to lower nutrient discharges to coastal seas. However, decrease of phosphorus (P) loads was much more efficient than that of nitrogen $(\mathrm{N})$ (Turner et al. 2003), which resulted in increasing dissolved inorganic nitrogen to dissolved inorganic phosphorus (DIN : DIP) ratios (Justic et al. 1995; Turner et al. 2003). The classical view, where coastal seas are characterized as $\mathrm{N}$ limited (Hecky and Kilham 1988; Howarth and Marino 2006) is now challenged by studies that show a prevalence

*Correspondence: julia.grosse@yahoo.com or eric.boschker@nioz.nl

Additional Supporting Information may be found in the online version of this article. of P-limitation (Philippart et al. 2007; Loebl et al. 2009; Burson et al. 2016).

Different approaches are available to determine the limiting nutrient for example by assessing available DIN and DIP concentrations or resulting DIN : DIP ratios (Redfield et al. 1963; Tilman and Kilham 1976; Goldman and Glibert 1983). The activity of the alkaline phosphatase enzyme can furthermore identify individual phytoplankton groups that are limited by DIP within a community (Dyhrman and Palenik 1997; González-Gil et al. 1998). Increased C : $\mathrm{N}$ or C : P ratios in phytoplankton indicate that DIN and DIP were the limiting nutrient, respectively. $\mathrm{C}: \mathrm{N}: \mathrm{P}$ ratios reflect variations in the compound composition, because major cellular biomolecules differ in their requirement for $\mathrm{C}, \mathrm{N}$, and $\mathrm{P}$ (Klausmeier et al. 2004). For example, carbohydrates $(\mathrm{CH})$ and fatty acids (FA) only contain C, while amino acids (AA), nucleic acids and polar membrane lipids require also $\mathrm{N}, \mathrm{P}$ or both. Under $\mathrm{N}$ - and/or P-deficiency C-rich storage compounds, such as $\mathrm{CH}$ or triglycerides, are preferably accumulated by microalgae (Granum et al. 2002; Borsheim et al. 2005). These changes in cellular composition may lead to a decline in the nutritional value of phytoplankton and potentially affect the structure and functioning of the entire food 
web (Sterner et al. 1993; Plath and Boersma 2001). Given the substantial changes currently occurring in coastal nutrient cycles, it is expected that the biomolecule composition of coastal phytoplankton undergoes drastic changes as well.

Nutrient addition bioassays are also commonly used to determine the limiting nutrients. In these experiments, nutrients are added in different combinations and changes in phytoplankton growth or biomass are compared. Changes in fluorescence, chlorophyll content or primary production are used as indicator but the required incubation periods to detect reliable changes are 2 d or more (Mills et al. 2004; Bonnet et al. 2008; Moisander et al. 2012). Bioassays have to last even longer (weeks) when changes in the concentration of biomolecule groups are investigated (Lynn et al. 2000; Mock and Kroon 2002). The long-term incubations detect an increase of primary production resulting from the increase in necessary growth machinery but they have the disadvantage that undesired changes in the phytoplankton community composition can occur over these longer periods that lead to not-field relevant results (Beardall et al. 2001).

However, the synthesis of the building blocks of the necessary growth machinery should be expected to occur on much shorter timescales and may be a much faster way to investigate the effects of nutrient limitation on biomolecule profiles. A few studies investigated the concurrent allocation of ${ }^{14} \mathrm{C}$ radioactive carbon into several biomolecule fractions (polysaccharides, proteins, and lipids) in natural phytoplankton communities (Lindqvist and Lignell 1997; Suárez and Marañón 2003), but they were not capable of distinguishing between structural and storage compounds, thereby lacking detailed information about the consequences of nutrient limitation of the cells. Recent method developments in stable isotope analysis make it now possible to measure concentrations and synthesis rates on the level of individual $\mathrm{CH}$, AA, and FA (Boschker 2004; McCullagh et al. 2006; Boschker et al. 2008) and apply them directly in field investigations (Grosse et al. 2015). The individual compounds can also be summed to biomolecule subgroups such as storage and structural CH or FA (Grosse et al. 2015) and allow for a complex analysis of compound dynamics. Combining bioassays with the isotope-enrichment approach allows short incubation periods $(\leq 24 \mathrm{~h})$, avoids undesired artifacts and allows studying interactions between nutrients and biomolecule pools.

The present study investigates the simultaneous biosynthesis of $\mathrm{CH}, \mathrm{AA}$, and $\mathrm{FA}$ by phytoplankton to provide insight into the effects of nutrient limitation on the biochemical fate of photosynthetically fixed $\mathrm{C}$ in coastal seas. We hypothesize that seasonal and spatial shifts in nutrient availability influence the biomolecule composition and synthesis of phytoplankton field populations, and expect that the effects of $\mathrm{N}$ - or P- limitation may be different. To address this hypothesis we conducted five cruises in the North Sea to characterize biomolecule dynamics in phytoplankton field populations during various stages of the spring bloom and

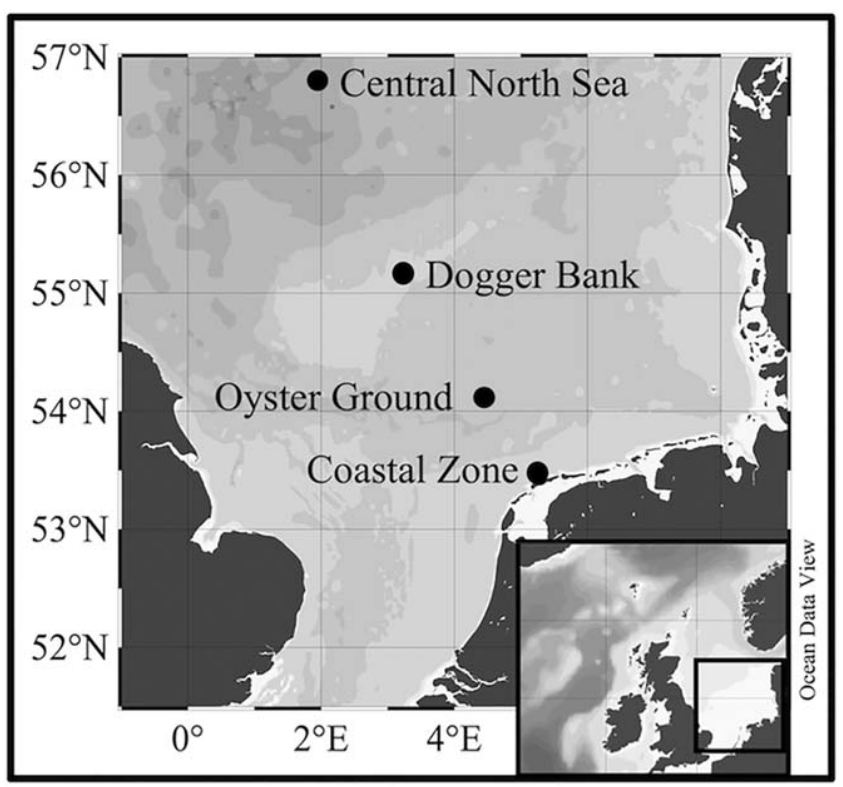

Fig. 1. Map of stations revisited during five cruises in 2011-2013.

thereafter, which covered a wide range of nutrient limitations and phytoplankton communities. Furthermore, we conducted short-term (24-72 h) nutrient addition experiments in order to identify nutrient specific effects in phytoplankton biomolecule biosynthesis patterns.

\section{Study sites and methods}

\section{Field campaigns}

Five cruises were conducted in the North Sea with the RV Pelagia, spread over 3 yr covering a transect from the Dutch coast toward the center of the North Sea (Fig. 1). Timing was such that they covered pre-spring bloom conditions in March, various stages of the spring bloom in April and May and summer conditions in August. The cruises took place on 25-31 May 2011, 15-30 August 2011, 08-12 May 2012, 15-25 March 2013 and 24 April-04 May 2013.

The temporal gradient followed the succession of nutrient and phytoplankton dynamics during a seasonal cycle, while the spatial gradient allowed investigation of different nutrient settings. The coastal zone station (CZ) is very shallow $(8 \mathrm{~m})$ and therefore completely mixed and its close proximity to shore $(7 \mathrm{~km})$ makes this station most affected by runoff from the river Rhine (salinities $<32$ PSU, Table 1). The Oyster Ground (OG) can show coastal or Atlantic Ocean influences, depending on the movement of the Frisian Front, which is situated in the broad zone around $54^{\circ} \mathrm{N}$ (Peeters and Peperzak 1990). The Dogger Bank (DB) shows low nutrient availability throughout the year and due to its shallowness $(30 \mathrm{~m})$ does not display stratification. The central North Sea (CNS) shows the largest influence of Atlantic Ocean water, which is low in nutrients, and thermally induced 
Table 1. Environmental data for all stations and cruises. $<\mathrm{DL}=$ below detection limit; $\mathrm{DL}$ for $\mathrm{Si}(\mathrm{OH})_{4}$ is at $0.03 \mu \mathrm{mol} \mathrm{L}^{-1}$.

\begin{tabular}{|c|c|c|c|c|c|c|c|c|c|}
\hline Station (\#) & $\begin{array}{c}\text { Salinity } \\
{[-]}\end{array}$ & Temperature $\left[{ }^{\circ} \mathrm{C}\right]$ & $\begin{array}{c}\mathrm{NO}_{3}^{-} \\
{[\mu \mathrm{mol} \mathrm{L}} \\
{[}\end{array}$ & $\begin{array}{c}\mathrm{NO}_{2}^{-} \\
{\left[\mu \mathrm{mol} \mathrm{L}{ }^{-1}\right]}\end{array}$ & $\begin{array}{c}\mathrm{NH}_{4}^{+} \\
{\left[\mu \mathrm{mol} \mathrm{L}^{-1}\right]}\end{array}$ & $\begin{array}{c}\mathrm{PO}_{4}^{3-} \\
{\left[\mu \mathrm{mol} \mathrm{L}^{-1}\right]}\end{array}$ & $\begin{array}{c}\mathrm{Si}(\mathrm{OH})_{4} \\
{\left[\mu \mathrm{mol} \mathrm{L}^{-1}\right]}\end{array}$ & DIN : DIP & DIN : Si \\
\hline \multicolumn{10}{|l|}{ Coastal Zone } \\
\hline April (2) & 31.2 & 6.8 & 15.5 & 0.43 & 0.34 & 0.05 & 0.13 & 325 & 125 \\
\hline Mid May (3) & 31.8 & 11.5 & 7.5 & 0.26 & 1.8 & 0.05 & 0.37 & 191 & 26 \\
\hline End May (4) & 34.6 & 12.1 & 3.1 & 0.24 & 2.3 & 0.09 & 1.1 & 63 & 5 \\
\hline \multicolumn{10}{|l|}{ Oyster Ground } \\
\hline March (6) & 34.7 & 4.2 & 9.7 & 0.11 & 0.16 & 0.54 & 6.3 & 18 & 2 \\
\hline April (7) & 34.5 & 5.6 & 0.68 & 0.08 & 0.33 & 0.04 & $<\mathrm{DL}$ & 27 & $\mathrm{~N} / \mathrm{A}$ \\
\hline Mid May (8) & 34.7 & 8.7 & 0.63 & 0.04 & 0.61 & 0.16 & 1.4 & 8 & 0.9 \\
\hline End May (9) & 34.4 & 10.5 & 0.12 & 0.02 & 0.34 & 0.03 & 0.77 & 16 & 0.6 \\
\hline August (10) & 34.7 & 16.6 & 0.01 & 0.01 & 0.10 & 0.13 & 2.2 & 1 & 0.1 \\
\hline Mid May (13) & 35.0 & 9.3 & 0.02 & 0.01 & 0.18 & 0.06 & 0.09 & 4 & 2 \\
\hline End May (14) & 34.9 & 11.6 & 0.01 & 0.01 & 0.08 & 0.09 & 0.44 & 1 & 0.2 \\
\hline \multicolumn{10}{|c|}{ Central North Sea } \\
\hline March (15) & 35.1 & 5.1 & 6.2 & 0.17 & 0.14 & 0.53 & 2.5 & 12 & 3 \\
\hline April (16) & 35.1 & 5.8 & 0.04 & 0.02 & 0.18 & 0.16 & 0.28 & 2 & 0.9 \\
\hline Mid May (17) & 35.0 & 8.1 & 0.76 & 0.07 & 0.45 & 0.17 & 0.84 & 8 & 2 \\
\hline August (18) & 34.9 & 14.6 & 0.01 & 0.01 & 0.08 & 0.02 & 0.76 & 5 & 0.1 \\
\hline
\end{tabular}

stratification occurs during summer when a deep chlorophyll maximum may develop (Van Haren et al. 1998; Weston et al. 2005).

Water column distribution of salinity, temperature and photosynthetically available radiation were obtained using a Sea-Bird SBE911+ CTD sampler (Sea-Bird Electronics, U.S.A.).

\section{Nutrient addition experiments}

Sub-surface water $(7 \mathrm{~m})$ for incubation experiments, nutrients, and pigment analysis was collected shortly before sunrise using a sampling rosette with 24 Niskin bottles $(12 \mathrm{~L})$ and directly transferred into $10 \mathrm{~L}$ carboys. Due to space limitations on board, the required sample volume and the extensiveness of sample preparation before analysis we only chose three nutrient addition treatments and a control, which were set up in duplicate: (1) a control incubation with no added nutrients, (2) addition of $80 \mu \mathrm{mol} \mathrm{L}{ }^{-1} \mathrm{NaNO}_{3}(+\mathrm{N}$ treatment), (3) addition of $5 \mu \mathrm{mol} \mathrm{L}{ }^{-1} \mathrm{~K}_{2} \mathrm{HPO}_{4}(+\mathrm{P}$ treatment) and (4) addition of $80 \mu \mathrm{mol} \mathrm{L}{ }^{-1} \mathrm{NaNO}_{3}, 5 \mu \mathrm{mol} \mathrm{L}{ }^{-1}$ $\mathrm{K}_{2} \mathrm{HPO}_{4}$ and $80 \mu \mathrm{mol} \mathrm{L}{ }^{-1} \mathrm{Si}(\mathrm{OH})_{4}$ (+NPSi treatment). All carboys were enriched with ${ }^{13} \mathrm{C}$-sodium bicarbonate $\left(99 \%{ }^{13} \mathrm{C}\right)$ to a concentration of $200 \mu \mathrm{mol} \mathrm{L} \mathrm{L}^{-1}$. Absolute ${ }^{13} \mathrm{C}$-DIC enrichment was measured in the laboratory (Grosse et al. 2015) and reached final labeling concentrations of $1.5-2 \%$ of ambient dissolved inorganic carbon (DIC) concentration.
Carboys were placed in flow-through incubators on deck and continuously flushed with seawater to assure in situ temperatures. The white carboys and additional shading on top of the incubators reduced light to similar levels as encountered at the sampling depth, without inducing shifts in the available light spectrum. The incubation experiments lasted $24 \mathrm{~h}$ and were terminated by splitting each carboy's content into four equal volumes and filtering these over precombusted GF/F filters (Whatman, $47 \mathrm{~mm}, 0.45 \mu \mathrm{m}$ poresize, $4 \mathrm{~h}$ at $450^{\circ} \mathrm{C}$ ). Between $0.3 \mathrm{~L}$ and $2.0 \mathrm{~L}$, depending on the phytoplankton density, were filtered for particulate organic carbon (POC), neutral $\mathrm{CH}, \mathrm{AA}$, and FA analysis. All filters were stored frozen at $-80^{\circ} \mathrm{C}$ until analysis (POC) or extraction of the biomolecules. Initial, unlabeled samples were also taken to determine background $\delta^{13} \mathrm{C}$ values for POC and individual biomolecules as well as pigment and nutrient concentrations.

Nutrient additions lasting $72 \mathrm{~h}$ were also carried out at the $\mathrm{CZ}$ and $\mathrm{DB}$ during selected cruises to investigate if longer-term changes in biomolecule synthesis differed from shorter-term $24 \mathrm{~h}$ incubations. Therefore, a second set of nutrient treatments was set-up (control, $+\mathrm{N},+\mathrm{P},+\mathrm{NPSi}$, in duplicates) concurrently with the $24 \mathrm{~h}$ incubations, the ${ }^{13} \mathrm{C}$-sodium bicarbonate tracer was added after $48 \mathrm{~h}$ and the incubations were terminated after $72 \mathrm{~h}$ as described above. 


\section{Extraction and analysis of biomolecules}

Detailed descriptions of extraction protocols for biomolecules (CH, AA, and FA), LC- and GC/C-IRMS systems as well as compound separation protocols and conditions were published in Grosse et al. (2015) and references therein. In short, $\mathrm{CH}$ samples were acid hydrolyzed and measured by LC/IRMS using an Aminex HPX-87H column, which separates glucose (Glu) from all other carbohydrates, while galactose, xylose, mannose, and fructose co-elute in a second peak. A third peak contains fucose, arabinose and ribose. Glu is also part of storage compounds and was therefore reported separately from all other $\mathrm{CH}$, which were referred to as structural $\mathrm{CH}$ hereafter. AA samples were acid hydrolyzed and analyzed by LC/IRMS using a Primsep A column, which separates a total of 18 individual AA (McCullagh et al. 2006).

FA samples were extracted following the protocol of Bligh and Dyer (1959) and subsequently separated into storage lipids, glycolipids, and phospholipids by silicate column chromatography. However, it has recently been shown that the phospholipid fraction also contains other non-P containing intact polar lipids (Heinzelmann et al. 2014). The glycolipidand phospholipid fraction were therefore combined and are further referred to as structural, membrane-derived lipids. After derivatization to fatty acid methyl esters (FAMEs), they were analyzed by GC/C-IRMS using the column BPX-70. Fatty acids were notated $\mathrm{A}: \mathrm{B} \omega \mathrm{C}$, where $\mathrm{A}$ is the number of carbon molecules in the fatty acid, $\mathrm{B}$ the number of double bonds and $\mathrm{C}$ the position of the first double bond relative to the aliphatic end.

\section{Calculation of ${ }^{13} \mathrm{C}$ uptake rates}

Carbon stable isotope ratios are expressed in the $\delta^{13} \mathrm{C}$ notation: $\delta^{13} \mathrm{C}(\%)=\left(\left(R_{\text {sample }} / R_{\mathrm{VPDB}}\right)-1\right) \times 1000$, where $R_{\text {sam- }}$ ple and $R_{\text {VPDB }}$ denote the ${ }^{13} \mathrm{C} /{ }^{12} \mathrm{C}$ ratio in the sample and the international standard, Vienna Pee Dee Belemnite $\left(R_{\mathrm{VPDB}}=0.0111802\right)$, respectively.

Incorporation of ${ }^{13} \mathrm{C}$ into bulk carbon as well as individual compounds is reflected as excess (above background) ${ }^{13} \mathrm{C}$ and was expressed as specific uptake after correction for enrichment of the DIC-pool (difference $\delta^{13} \mathrm{C}_{\text {DICsample }}$ at end

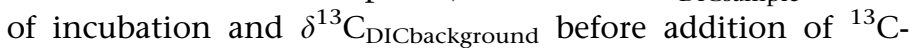
$\mathrm{DIC})$, POC concentration and incubation time in (nmol $\mathrm{C}$ $\left.(\mu \text { mol POC })^{-1} \mathrm{~d}^{-1}\right)$.

Concentrations and biosynthesis rates were calculated for each individual compound per duplicate and added together to obtain values for each biomolecule group (total AA, storage and structural FA, and storage (glucose) and structural $\mathrm{CH})$. Afterwards averages and standard deviations were calculated $(n=2)$. Biomolecule concentrations and C-fixation rates throughout the text were reported relative to cumulative $P O C$ concentrations and $\mathrm{C}$-fixation rates $(\mathrm{AA}+\mathrm{FA}+\mathrm{CH}=100 \%)$, respectively. Unidentified contributions were only included into total POC concentrations and bulk C-fixation rates.

\section{Other analyses}

Pigments were extracted in 90\% acetone, separated by high pressure liquid chromatography and identified and quantified using commercially available standards (Dijkman and Kromkamp 2006). Samples for dissolved nutrients were filtered through $0.2 \mu \mathrm{m}$ polycarbonate filters and concentrations of nitrate $\left(\mathrm{NO}_{3}^{-}\right)$, nitrite $\left(\mathrm{NO}_{2}^{-}\right)$, ammonium $\left(\mathrm{NH}_{4}^{+}\right)$, phosphate $\left(\mathrm{PO}_{4}^{3-}\right)$, and silicate $\left[\mathrm{Si}(\mathrm{OH})_{4}\right]$ were analyzed using a QuAAtro autoanalyzer (SEAL Analytical) according to manufacturer's instructions. Total dissolved inorganic nitrogen (DIN) was calculated as the sum of $\mathrm{NO}_{3}^{-}, \mathrm{NO}_{2}^{-}$, and $\mathrm{NH}_{4}^{+}$. Particulate organic carbon (POC) filters were lyophilized overnight and a section of the filter (1/4 or less depending on the amount of material on the filter) was acidified over fuming $\mathrm{HCl}$ before being packed into tin cups. The analysis for organic carbon content and $\delta^{13} \mathrm{C}$ values was performed using the same EA-IRMS system described elsewhere (Grosse et al. 2015).

\section{Statistical analysis}

To explore differences in phytoplankton community structure, principle component analysis (PCA) was performed with the relative contribution (\%) of (1) individual structural FA concentrations to total structural FA concentrations (nmol C ( $\mu$ mol POC $)^{-1}$ ) and (2) individual pigment concentrations to total pigment concentrations $\left(\mu \mathrm{g} \mathrm{L}^{-1}\right)$. The package CRAN:factoMineR in the open source software $\mathrm{R}$ was used for the PCA analysis using a correlation matrix. Only FA found in eukaryotic algae and cyanobacteria were used, while FA commonly found in heterotrophic bacteria were omitted from the PCA (cf. Dijkman and Kromkamp 2006). The PCA matrix for pigments included all quantified pigments, while all chlorophyll degradation products were excluded, e.g., pheophytin and pheophorbide.

\section{Results and discussion}

\section{Seasonal succession}

Inorganic nutrients concentrations were highest at the $\mathrm{CZ}$ and generally decreased farther offshore as well as throughout the year (Fig. 2a-d). The Redfield N : P : Si ratio of $16: 1: 16$ can be used to coarsely identify if phytoplankton growth is limited by either DIN, DIP, or Si. According to this ratio, the $\mathrm{CZ}$ was P-limited during all cruises and co-limited by Si until End May. The OG farther offshore was $\mathrm{P} / \mathrm{Si}$ colimited in March and April before switching to N-limitation thereafter. Nutrient ratios at the DB and CNS indicated Nlimitation during all cruises with a concurrent $\mathrm{Si}$ colimitation between March and Mid May (exception CNS/ April, Table 1). However, ambient DIN, DIP, and Si concentrations in March were high enough that they were not limiting phytoplankton growth at all stations.

Phytoplankton biomass and productivity showed either one or two seasonal peaks and were generally highest at the $\mathrm{CZ}$, while the DB showed lowest values (Fig. 2e-h). To 

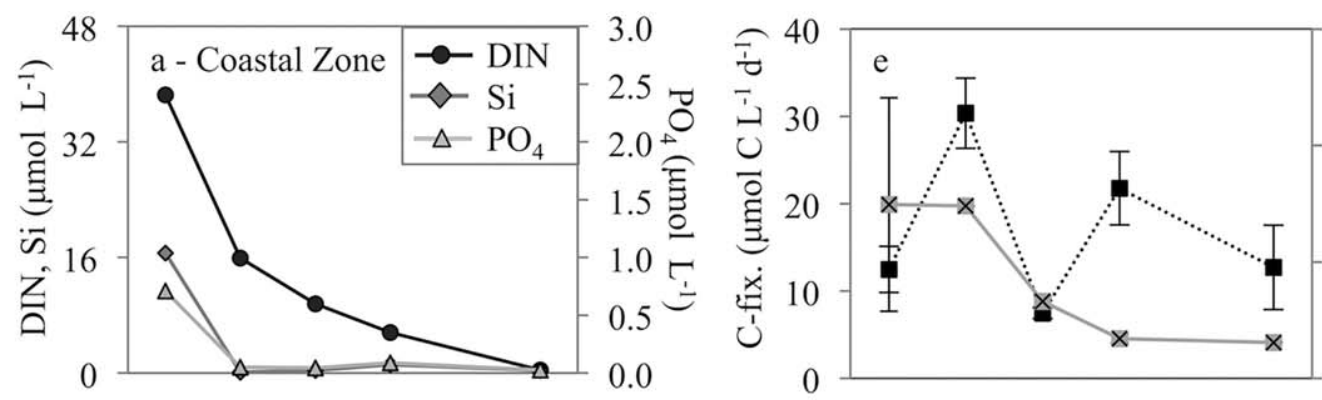

30

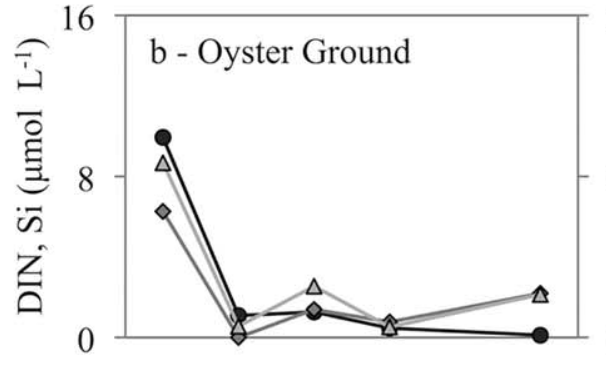

1.0
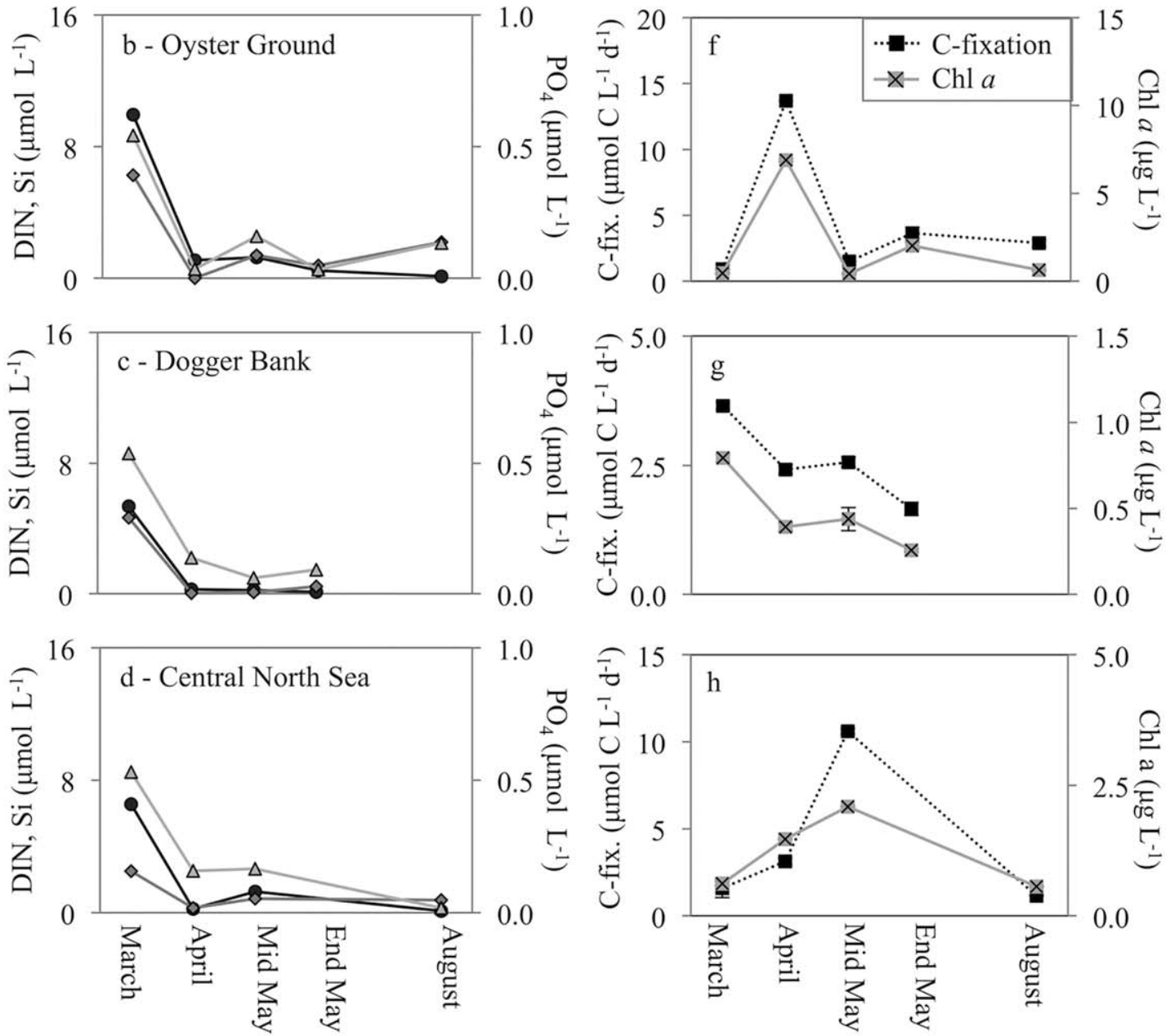

Fig. 2. Dissolved nutrient concentrations for each station (a-d). Please note that nutrient $Y$-axes were scaled to display a DIN : Si : DIP ratio of $16: 16: 1$. Rates of bulk C-fixation and biomass estimates (as Chlorophyll $a[\mathrm{Chl} a]$ ) per volume for different stations and cruises (e-h, note differences in $Y$-axes scales).

establish differences in phytoplankton community composition PCAs were performed using biomarker molecules (Fig. 3). The composition of individual FA differs greatly between phytoplankton groups, especially in the structural FA fraction. For example, diatoms are enriched in $16: 1 \omega 7$ and $20: 5 \omega 3$ and they contain diatom specific FA $16: 3 \omega 4$ and 16:4 $\omega 1$ (Dalsgaard et al. 2003; Dijkman and Kromkamp 2006). In contrast flagellates, including dinoflagellates, the Prymnesopphyceae Phaeocystis and nano-flagellates, synthesize higher amounts of 22:6 $\omega 3$ and contain the flagellate specific FA 18:5 $\omega 3$ and 18:5 $\omega 5$, while increase amounts of $16: 4 \omega 3$ and 18:4 $\omega 3$ indicate the presence of green algae (Dijkman and Kromkamp 2006). Natural communities consist of multiple phytoplankton groups (Barnard et al. 2004), however one of them can dominate being the main contributor to total biomass (McQuatters-Gollop et al. 2007a). PCA of structural FA concentrations revealed three different communities (Fig. 3a). Communities dominated by diatoms 

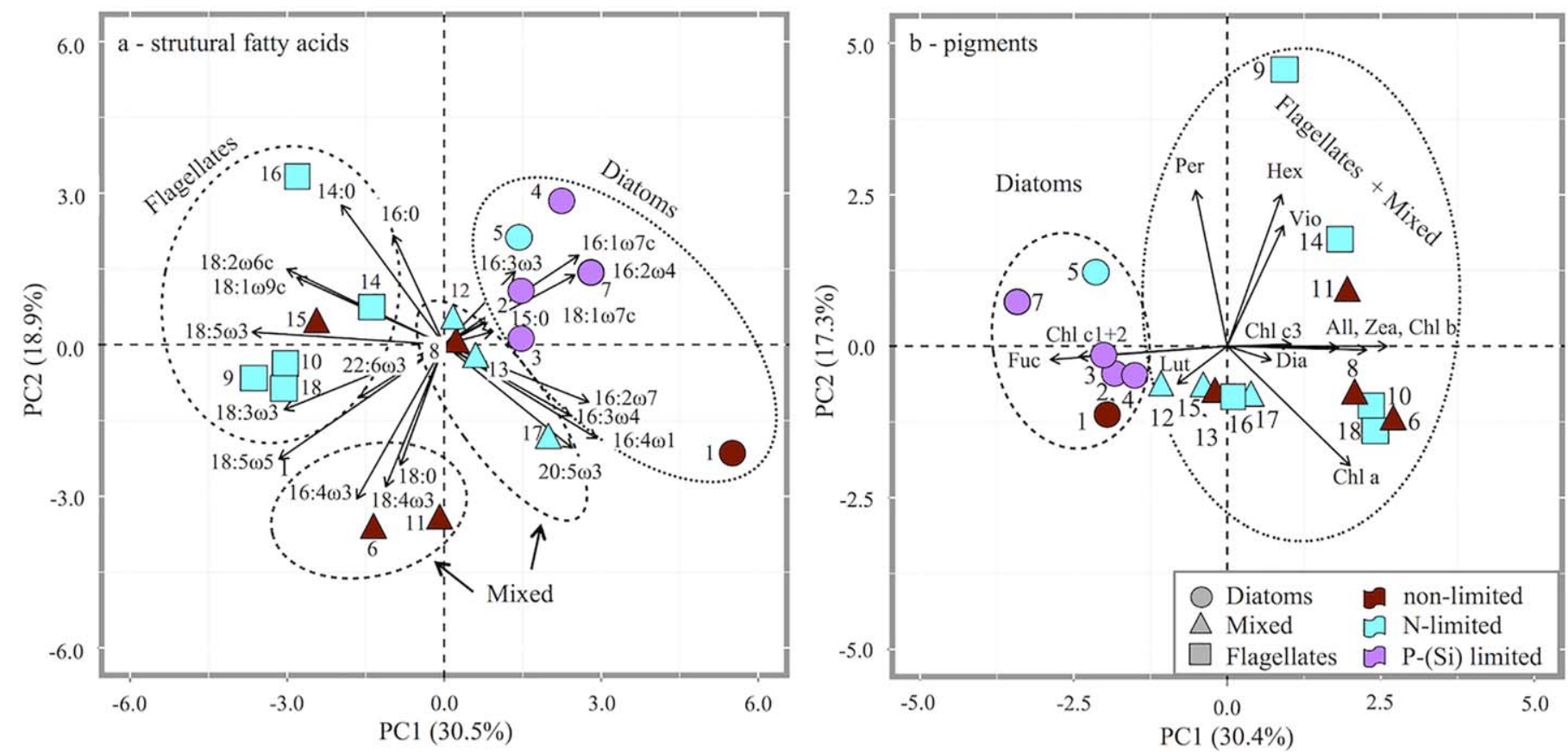

Fig. 3. PCA biplot of relative contribution of individual FA to the structural FA fraction (a) and pigments (b). Symbol shape refers to the phytoplankton community and symbol color indicates prevailing nutrient limitation. Numbers next to symbols refer to individual stations/cruises according to Table 1. All = Alloxanthin, Chl $a=$ chlorophyll $a, \mathrm{Chl} b=$ chlorophyll $b, \mathrm{Chl} c 1+2=$ chlorophyll $c_{1}+2$, Chl $c 3=$ chlorophyll $c_{3}$, Dia $=$ Diadinoxanthin, Fuc $=$ Fucoxanthin, Hex =19-Hexanoyloxyfucoxanthin, Lut $=$ Lutein, Per $=$ Peridinin, Vio $=$ Violxanthin, Zea $=$ Zeaxanthin

("diatom-dominated," based on high amounts of $16: 1 \omega 7$ and 20:5 03 ) were found at the CZ during all cruises as well as at the OG in April. Communities that were dominated by flagellates ("flagellate-dominated," based on high amounts of

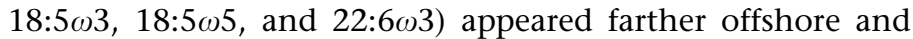
later during the season, e.g., DB/End May and CNS/August (Stns. \#14, 18). Several stations could not clearly be classified as either diatom- or flagellates-dominated and were referred to as "Mixed." These communities contained either high amounts of green algae biomarker FA $(16: 4 \omega 3,18: 4 \omega 3$; OG and DB in March (Stns. \#6, 11]) or identification was uncertain because the community was transitioning from a diatomdominated to flagellate-dominated one (OG/Mid May, DB/ April, DB/Mid May, CNS/Mid May [Stns. \#8, 12, 13, 17]).

Pigments are also widely used to describe phytoplankton communities. Fucoxanthin and chlorophyll $c_{1+2}$ are usually associated with diatoms, while alloxanthin, chlorophyll $c_{3}$, 19-Hexanoyloxyfucoxanthin and peridinin are characteristic for flagellates (including dinoflagellates, Phaeocystis spp. and nanoflagellates). Several other pigments can identify the contribution of cyanobacteria (zeaxanthin) or green algae (chlorophyll $b$, lutein and violxanthin) (Wright and Jeffrey 2006). The PCA of pigment concentrations clearly separates the diatom-dominated communities from all others, agreeing with findings in the PCA of structural FA (Fig. 3). However, flagellate and mixed communities did not separate in the pigment data PCA (Fig. 3b). Overall, structural FA and pigment data agreed well with cell count data obtained on the same cruises (Burson et al. 2016). Phytoplankton communities showed the shift from diatom-dominated communities to into flagellate-dominated communities, which is typical for the North Sea (McQuatters-Gollop et al. 2007a) and developed earlier in the year with increasing distance to the coast.

\section{Response of phytoplankton to short-term nutrient additions}

Effects of nutrient additions were clearly visible in the synthesis of all five biomolecule groups within $24 \mathrm{~h}$ (Fig. 4). The clearest effect was observed in the AA fraction, where synthesis increased as fraction of cumulative C-fixation in at least one treatment in the majority of the experiments. Most stations showed increased AA synthesis in the $+\mathrm{N}$ and + NPSi treatments, identifying those stations as primarily Nlimited. Examples were the CZ in August (Stn. \#5), where AA synthesis increased in both treatments by $18 \% \pm 0 \%$ and $20 \% \pm 14 \%$, respectively, or the DB in Mid May (Stn. \#13), with an increase of $24 \% \pm 10 \%$ and $27 \% \pm 10 \%$ in the $+\mathrm{N}$ and +NPSi treatments, respectively. Some N-limited stations were also co-limited by $\mathrm{P}$ and/or Si. N/P co-limitation was detected at the CNS in Mid May (Stn. \#17), where AA synthesis increased in all three treatments relative to the control. An example for N/Si co-limitation would be the OG in End May (Stn. \#9), where AA synthesis in the $+\mathrm{N}$ treatment 


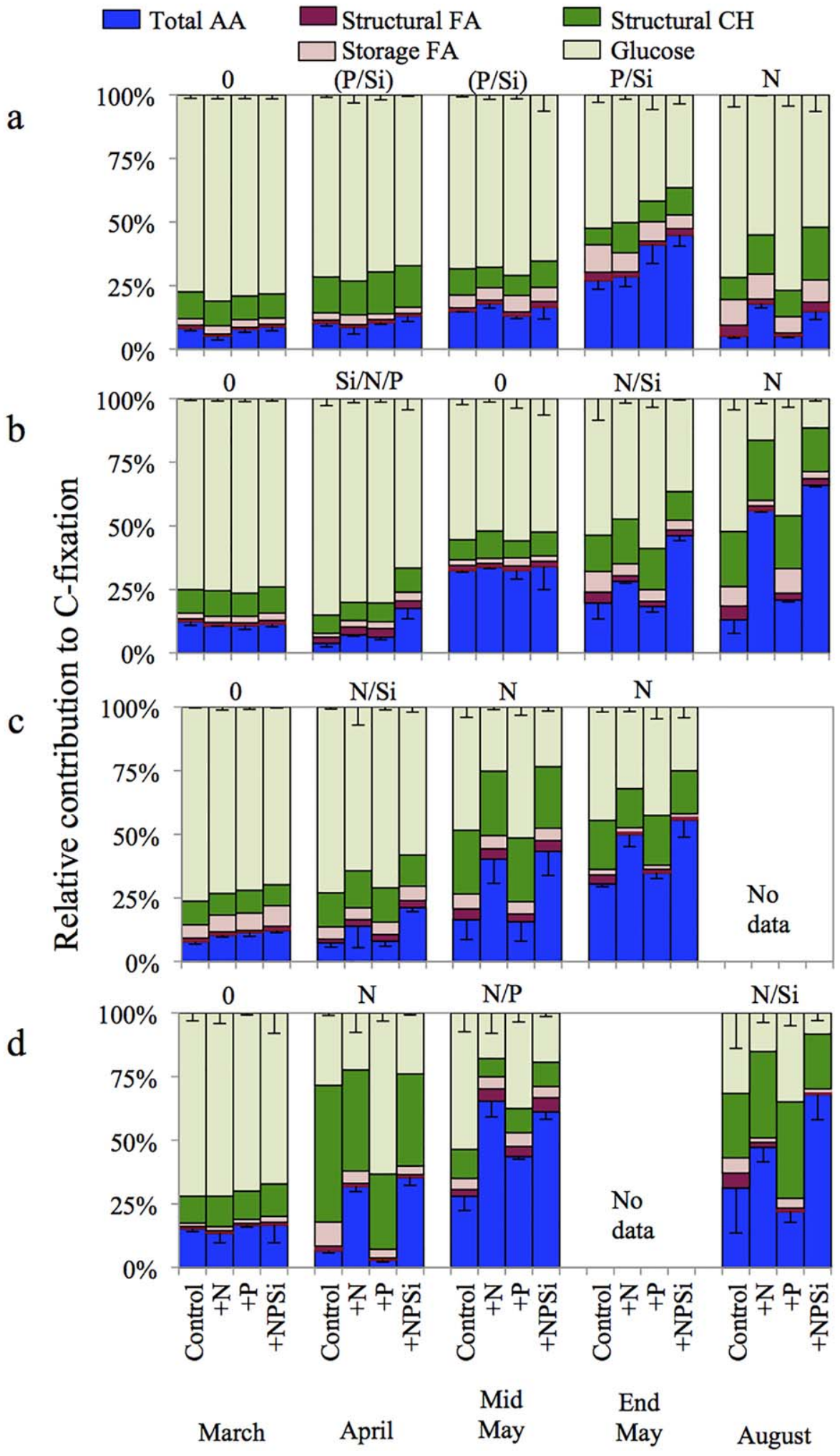

Fig. 4. Contribution of biomolecule groups to $\mathrm{C}$-fixation. All seasons and nutrient addition treatments are illustrated for $24 \mathrm{~h}$ incubations at the $\mathrm{CZ}$ (a), the OG (b), the DB (c), and the CNS (d). Control = no nutrients added. $+\mathrm{N}=$ addition of $80 \mu$ mol L $\mathrm{L}^{-1} \mathrm{NaNO}_{3} .+\mathrm{P}=$ addition of $5 \mu$ mol L $\mathrm{L}^{-1}$ $\mathrm{K}_{2} \mathrm{HPO}_{4}$. $+\mathrm{NPSi}=$ addition of $80 \mu \mathrm{mol} \mathrm{L}{ }^{-1} \mathrm{NaNO}_{3}, 5 \mu \mathrm{mol} \mathrm{L} \mathrm{L}^{-1} \mathrm{~K}_{2} \mathrm{HPO}_{4}$ and $80 \mu \mathrm{mol} \mathrm{L}{ }^{-1} \mathrm{Si}(\mathrm{OH})_{4}$. Inferred nutrient limitations are identified above each panel, $0=$ no clear limitation, $\mathrm{N} / \mathrm{P} / \mathrm{Si}=\mathrm{N}$-, $\mathrm{P}$ - and Si-limitation or combination thereof. $\mathrm{P} / \mathrm{Si}$ limitations in (brackets) could not be identified within $24 \mathrm{~h}$ and only yielded clear results after $72 \mathrm{~h}$ (see Fig. 5). Average are depicted $(n=2)$, but SD was only included for AA and Glu for clarity, and was overall $\sim 4 \%$ for total $\mathrm{AA}, \sim 1.5 \%$ for total FA, $\sim 4 \%$ for structural $\mathrm{CH}$ and $\sim 14 \%$ for Glu. 


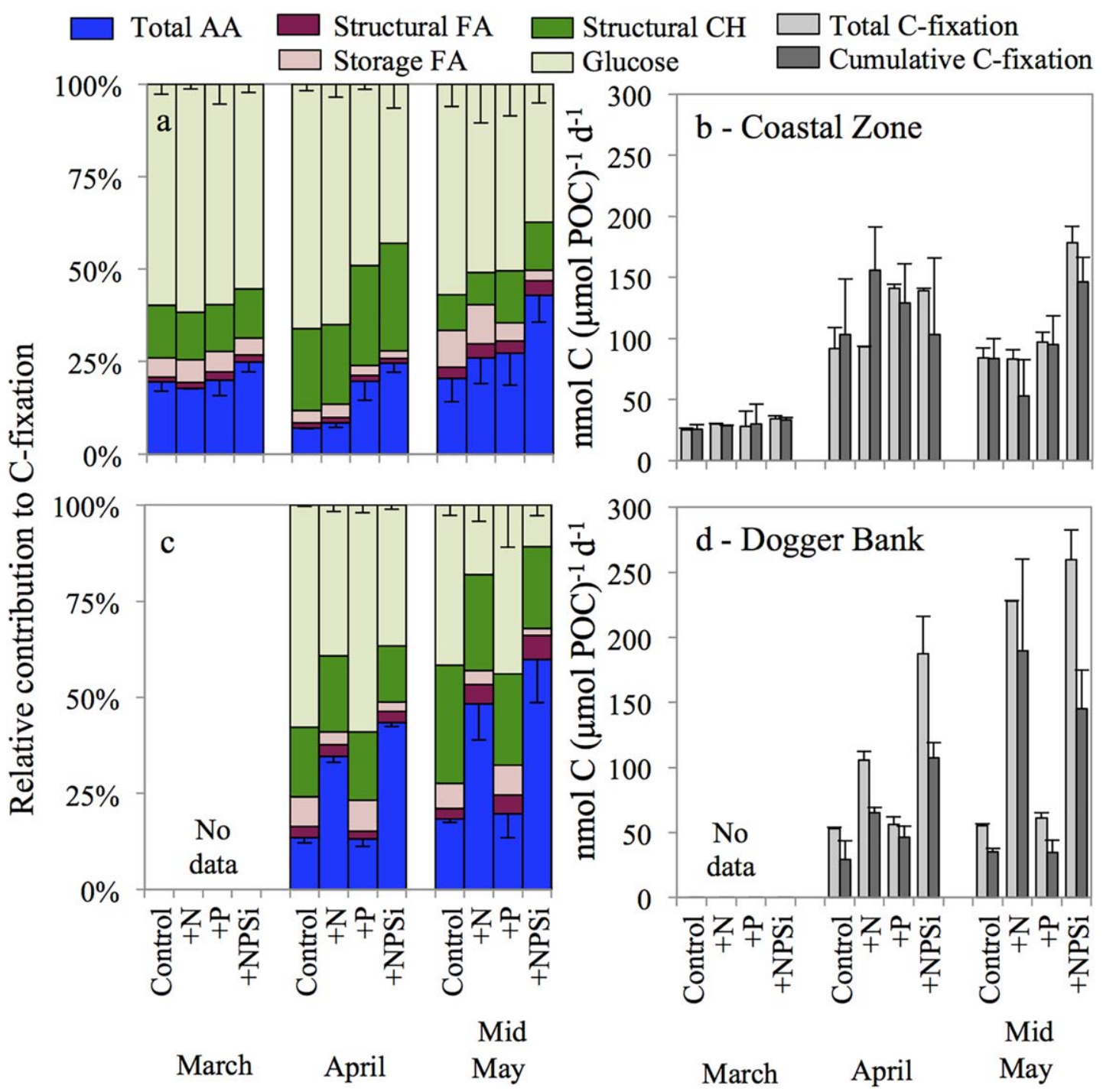

Fig. 5. Contribution of biomolecule groups to cumulative $C$-fixation at the $C Z$ (a) and the $D B$ (c) and comparison to bulk $C$-fixation rates (b, d), for $72 \mathrm{~h}$ nutrient additions. Shown are average, $n=2(\mathbf{a}, \mathbf{c})$ and average $\pm S D, n=2(\mathbf{b}, \mathbf{d})$. SD was only included for AA and Glu for clarity (a, c), and was overall $\sim 4 \%$ for total $\mathrm{AA}, \sim 1.5 \%$ for total $\mathrm{FA}, \sim 4 \%$ for structural $\mathrm{CH}$ and $\sim 14 \%$ for Glu.

increased only slightly $(8 \% \pm 1 \%)$, while the increase in the + NPSi treatment was $27 \% \pm 2 \%$, but no increase was detectable in the $+\mathrm{P}$ treatment. The highest overall increase in AA synthesis was measured at the OG station in August (Stn. \#10) with $53 \% \pm 1 \%$ in the $+\mathrm{NPSi}$ treatment. P-limitation was clearly identified at the CZ in End May (Stn. \#4), where AA biosynthesis increased by $14 \% \pm 8 \%$ in the $+\mathrm{P}$ treatment and by $18 \% \pm 5 \%$ in the + NPSi treatment. Potentially, changes in AA synthesis could also identify Si-limitation, e.g., OG in April (Stn. \#7) hardly showed an increase in AA synthesis for the $+\mathrm{N}$ and $+\mathrm{P}$ treatments $(3 \% \pm 1 \%$ and $2 \% \pm 1 \%$, respectively), but showed a $14 \% \pm 4 \%$ increase in the + NPSi incubations. A number of stations showed a limited or no effect of nutrient addition on biomolecule synthesis suggesting no clear macronutrient limitation, which mainly occurred in March, but also in April at the CZ and in Mid May at the CZ and OG. However, $72 \mathrm{~h}$ incubations did show clear responses at the $\mathrm{CZ}$ in April and Mid May (Stns. \#2, 3) identifying them as P/Si colimited (Fig. 5a,c). These responses were also clearly seen in the actual rate data, showing increases in the $+\mathrm{P}$ and + NPSi treatments in Mid May (see Supporting Information). This suggests that the response to the addition of the limiting nutrient was slower in P- than in N-limited phytoplankton. At several stations during selected cruises, Burson et al. (2016) conducted classical bioassays using changes in chlorophyll $a$ (Chl $a$ ) concentrations in parallel to compound specific bioassays. In general, both approaches identified the same limiting nutrients.

Diatom dominated communities were present at the $\mathrm{CZ}$ year-around as well as at the OG in April and were primarily limited by $\mathrm{P}$ and/or Si. Overall, diatom communities 


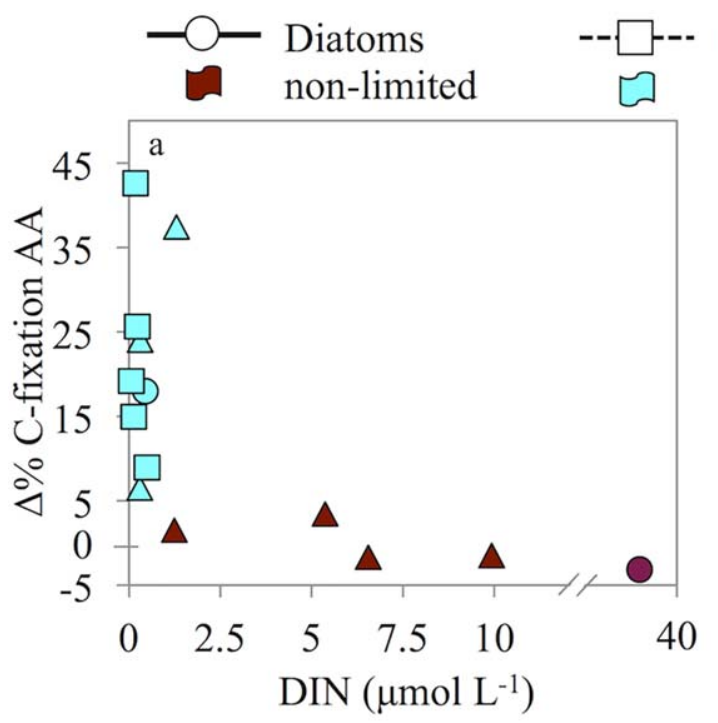

$\begin{array}{ll}\text { Flagellates } & \triangle \text { Mixed } \\ \text { N-limited } & \square \text { P- }(\text { Si }) \text { limited }\end{array}$
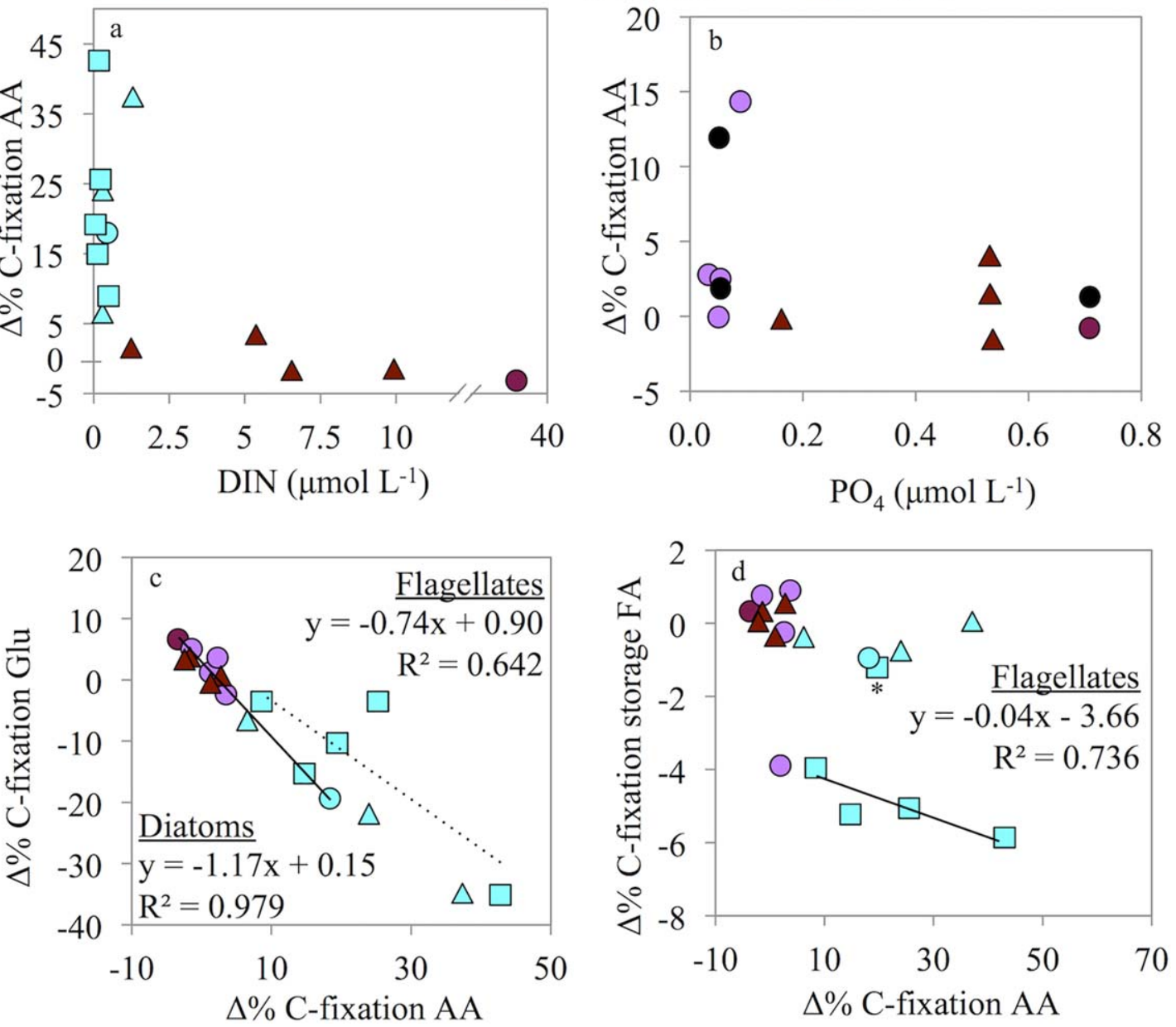

Fig. 6. Differences in biomolecule synthesis in $\mathrm{C}$-fixation between Control and $+\mathrm{N}$ treatments $(24 \mathrm{~h}, \mathbf{a}, \mathbf{c}$, d) and Control and $+\mathrm{P}$ treatments $(24 \mathrm{~h}$, $72 \mathrm{~h}, \mathbf{b})$. Changes in AA synthesis identified limiting DIN concentrations (a) and $\mathrm{PO}_{4}$ concentration (b). Black circles in panel B identify $72 \mathrm{~h}$ incubations at the CZ. Changes in carbon allocation into Glu and storage FA correlated with concurrent changes in AA synthesis are shown in panels (c) and (d), respectively. Intermediate communities are shown but not included into calculation of trend lines. In panel D one flagellate data point $\left({ }^{*}\right)$ was excluded from the respective correlation.

transitioned into N-limited flagellate communities, which were also co-limitation by $\mathrm{P}$ at several locations. At one station (OG/Mid May, Stn. \#13) the mixed community did not show a response to nutrient addition, suggesting a community that was transitioning into a flagellate dominated community after diatoms ran out of required nutrients, most likely silicate. Flagellate communities were only found at DIN concentrations lower than $0.6 \mu \mathrm{mol} \mathrm{L} \mathrm{L}^{-1}$ DIN. Nlimitation in diatom and mixed communities started at concentrations between 1.3 and $5.4 \mu \mathrm{mol} \mathrm{L}^{-1}$ DIN and P colimitation begun between 0.09 and $0.16 \mu \mathrm{mol} \mathrm{L}^{-1} \mathrm{PO}_{4}^{3-}$ (Fig. $6 \mathrm{a}, \mathrm{b})$. A significant response in AA biosynthesis after $72 \mathrm{~h}$ was only observed at the $\mathrm{CZ}$ in April, when the community transitioned towards flagellates (see below), which did not require additional silicate.
Nutrient limitation identified by the compound specific isotope approach agreed mostly with nutrient limitations indicated by the Redfield ratio (DIN : DIP : Si $=16: 1: 16$; Table 1; Fig. 2). However, absolute nutrient concentrations and community specific nutrient requirements have to be considered when discrepancies occur. For example, we found no limitation at the OG/Mid May (Stn. \#8), where DIN : DIP ratios of $8: 1$ indicated a potential N-limitation, or at the CZ/August (Stn. \# 5) where DIN : DIP ratios of $20: 1$ would have suggested nearly balanced growth, but we actually found strong N-limitation due to a low availability of DIN. Indeed, optimal $\mathrm{N}$ : $\mathrm{P}$ ratios for phytoplankton have been found to be species dependent and can range between 5 and 50, for species with low $\mathrm{N}$ and low P-requirements, respectively (Geider and LaRoche 2002; Quigg et al. 2003; 

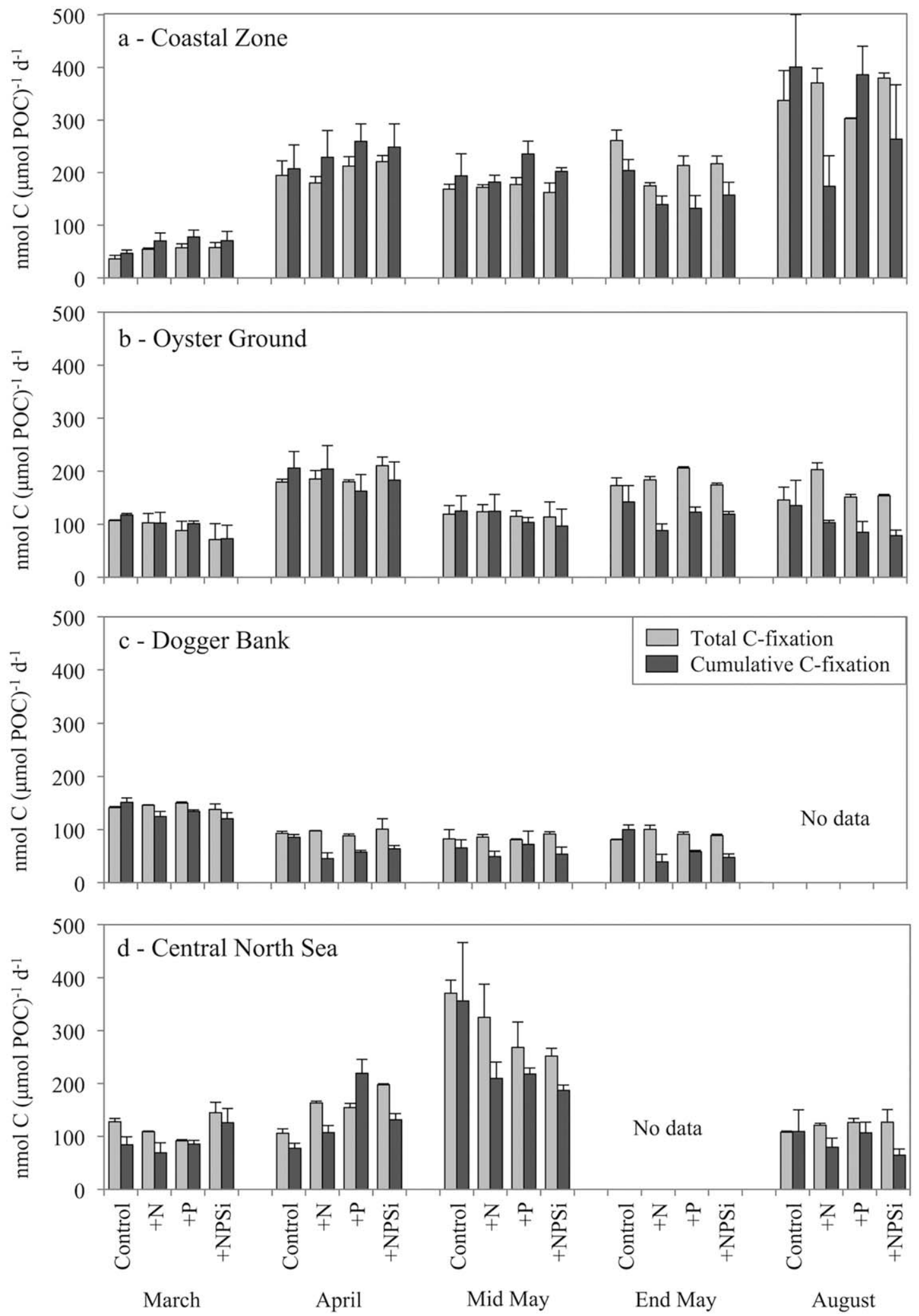

Fig. 7. Total $\mathrm{C}$-fixation and cumulative $\mathrm{C}$-fixation per $\mu \mathrm{mol} P \mathrm{POC}(\mathrm{CH}+\mathrm{AA}+\mathrm{FA})$ in different nutrient treatments in $24 \mathrm{~h}$ incubations at the $\mathrm{CZ}$ (a), the OG (b), the DB (c) and the CNS (d). Shown are average \pm (cumulative) SD, $n=2$. SD of cumulative carbon fixation is the sum of SD of Glu, structural $\mathrm{CH}, \mathrm{AA}$, structural and storage $\mathrm{FA}$. 

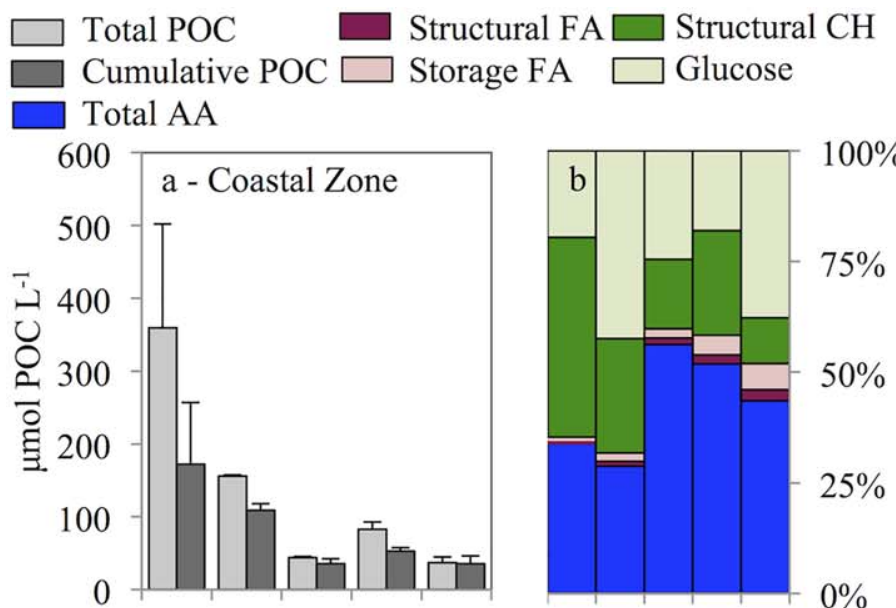

$100 \%$
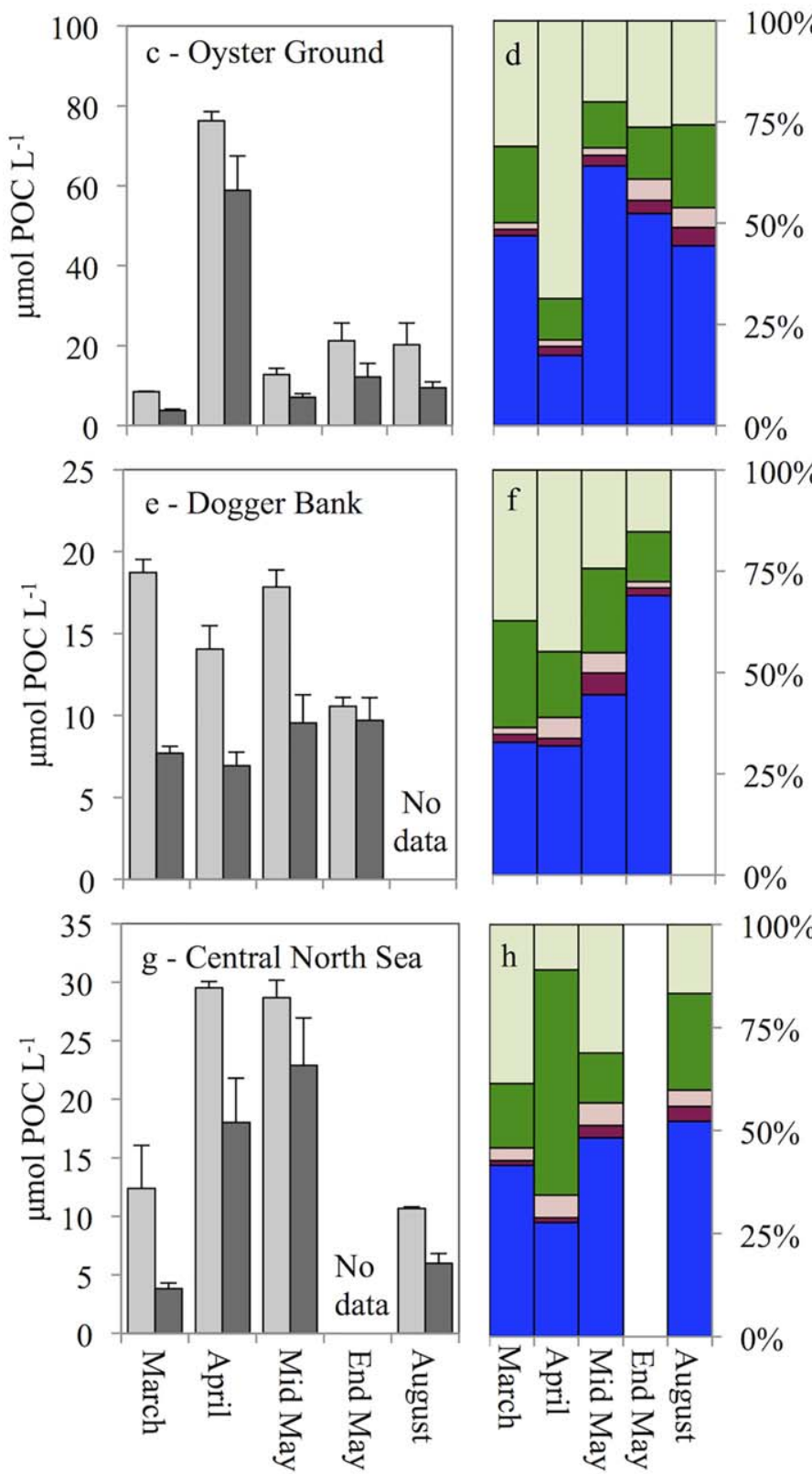

Klausmeier et al. 2004). Evidently, using the response of AA biosynthesis after nutrient addition seems to be a more reliant identifier of the limiting nutrient than using DIN : DIP ratios.

The increase in AA synthesis after addition of the limiting nutrient resulted in a concurrent decrease in glucose (Glu) synthesis at a similar magnitude and was greatest in N-limited communities (Fig. 6c). Under nutrient limited conditions storage Glu was the highest C-sink, which was immediately processed into other biomolecules when resources became available. Diatom and mixed communities primarily used Glu as C-storage, while flagellates also used storage FA (Fig. 6c,d). Changes in the synthesis of structural FA and structural $\mathrm{CH}$ changed between stations and seasons without a clear pattern emerging and may have been community specific responses rather than a response to resource limitation.

Changes in bulk C-fixation rates could not be used to determine the limiting nutrient because no systematic increase or decrease was observed after $24 \mathrm{~h}$ (Fig. 7), and only led to interpretable results after $72 \mathrm{~h}$ (Fig. 5). Cumulative carbon fixation rates $(24 \mathrm{~h})$ of $\mathrm{CH}, \mathrm{AA}$, and FA were mostly close to the total carbon fixation rates (bulk C-fixation), as determined from ${ }^{13} \mathrm{C}$-POC labeling, in all control incubations as well as in all nutrient treatments in March and at the $\mathrm{CZ}$ and OG until Mid May. Occasionally, values were above $100 \%$, but usually accompanied by higher standard deviations, probably due to experimental errors for instance during sample handling on board. At the other stations and seasons the cumulative C-fixation was clearly affected by the addition of the limiting nutrient, especially in treatments where AA synthesis increased substantially in flagellates dominated communities. There the cumulative Cfixation only explained $\sim 70 \%$ or less of bulk C-fixation (e.g., all stations in August [+N/+NPSi] and CNS in Mid May, Stns. \#5, 10, 14, 18, 17). The lowest amount of cumulative C-fixation was observed at the DB in End May (Stn. \#13) where it only explained $38 \% \pm 11 \%$ of bulk C-fixation in the + NPSi addition. Similar values were encountered after $72 \mathrm{~h}$, when cumulative C-fixation accounted for $\sim 100 \%$ or less, and explained as little as $56 \% \pm 5 \%$ (DB/Mid May) of bulk Cfixation, with one exception in the $+\mathrm{N}$ treatment at the $\mathrm{CZ}$ in April [Stn. \#2, 167\% $\pm 37 \%$ (Fig. 5)]. This discrepancy indicates that, when the limiting nutrient was added, $\mathrm{C}$ was allocated into a biomolecule pool that we did not investigate such as DNA and RNA. The increase in AA synthesis and consequently growth rates most likely requires higher synthesis of ribosomes and RNA (Dortch et al. 1983; Elser et al. 2000; Falkowski 2000).

Fig. 8. Concentrations of total $P O C$ are compared to cumulative $P O C$ of biomolecule groups in the left-side panel. Shown are average \pm (cumulative) SD, $n=2$. Contributions of biomolecule groups to cumulative $P O C$ are shown in the right-side panel. The different stations are shown at the CZ $(\mathbf{a}, \mathbf{b})$, OG $(\mathbf{c}, \mathbf{d}), \mathrm{DB}(\mathbf{e}, \mathbf{f})$, and CNS $(\mathbf{g}, \mathbf{h})$. 

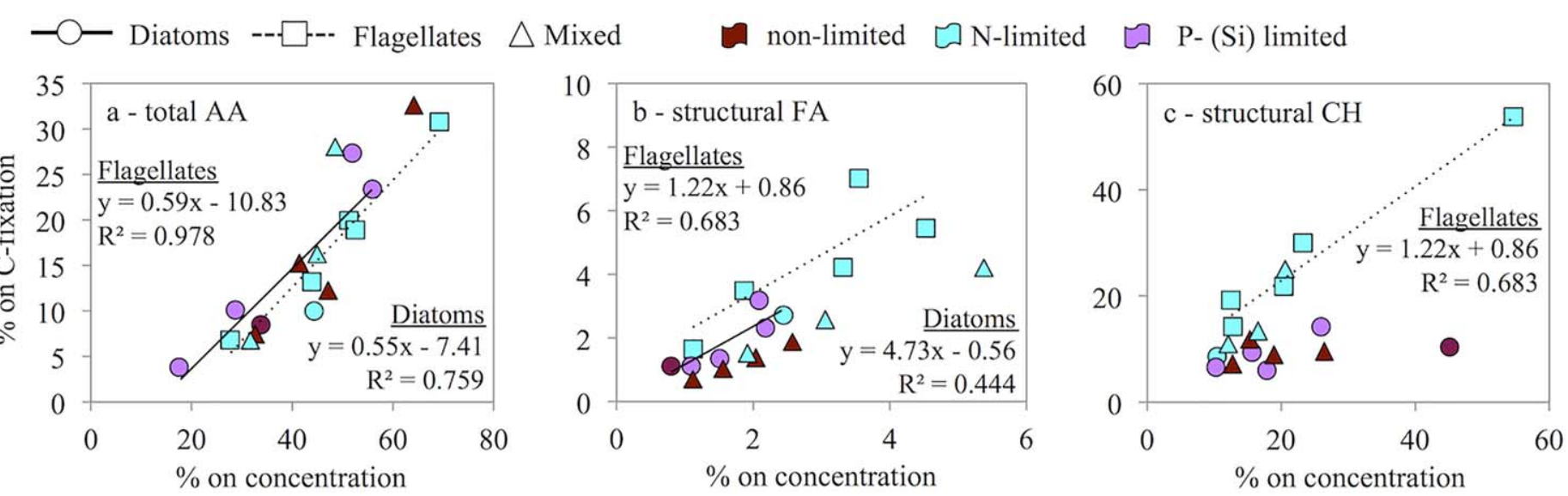

Fig. 9. Correlation of biomolecule concentrations (\%) contributing to POC concentration and \% of same biomolecules contributing to C-fixation in control incubations for amino acids (a), structural FA, (b), and structural $\mathrm{CH}$ (c). Diatom and flagellate communities are correlated separately; mixed communities are shown but not included into calculation of trend lines. Shown are averages, $n=2$.

AA synthesis responded to the relief of both $\mathrm{N}$ - and Plimitation, but was typically higher and faster in N-limited than in P-limited communities within the first $24 \mathrm{~h}$ (Figs. 4, $6 \mathrm{~b}, \mathrm{c})$. Synthesis of RNA, especially ribosomal RNA, is a major sink for $\mathrm{P}$ in phytoplankton and accounts for up to half of the P uptake (Van Mooy and Devol 2008; Hessen et al. 2010). P-limited phytoplankton typically down-regulates ribosome synthesis and its overall intracellular content, causing protein synthesis to be limited by the availability of $\mathrm{P}$ for RNA synthesis (Elser et al. 2000; Wang et al. 2014). After resupplying $\mathrm{P}$, the RNA and ribosome content needs to increase first thereby delaying enzyme and protein synthesis compared to N-limited phytoplankton causing an asymmetric response in $\mathrm{AA}$ synthesis between $\mathrm{N}$ - and P-limited incubations. However, the molecular structure of RNA requires $\mathrm{N}$ as well. It has to be assumed that eventually N-limitation can affect RNA synthesis in a similar way, resulting in a delayed response in AA synthesis after $\mathrm{N}$-addition because RNA synthesis has to precede AA synthesis. As expected, the response to the re-supply of nutrients became more similar in $\mathrm{N}$ - and P-limited phytoplankton after a longer incubation period (72 h, Fig. 5b,d). However, in un-amended control incubations, the good agreement between bulk C-fixation and cumulative C-fixation of $\mathrm{AA}, \mathrm{FA}$, and $\mathrm{CH}$ suggests that RNA/DNA formed a relatively minor C-pool and may have only become temporarily important during changes in nutrient status. In conclusion, the down-regulation of AA synthesis and the up regulation of storage compounds under nutrient limitation seem to be a general response of phytoplankton and result in decreased growth.

\section{Relationship between POC composition and biomolecule synthesis}

Biochemical composition of POC (Fig. 8) and biomolecule synthesis in the un-amended control incubations (Fig. 4) both showed substantial seasonal variations. Trends were very similar yielding remarkably strong relationships between biomolecule composition and synthesis (Fig. 9) and indicated that detrital contribution to POC concentration was probably relatively minor and that our biosynthesis data are field relevant. Generally, AA concentrations and synthesis were low in March. They decreased even further in April, ranging between $18 \% \pm 5 \%$ and $32 \% \pm 5 \%$ of POC concentration and $4 \% \pm 2 \%$ and $10 \% \pm 1 \%$ of biosynthesis, coinciding with strong nutrient limitation during the spring bloom. Maximum AA contributions were found in Mid May or End May, depending on the station and reached up to $64 \% \pm 1 \%$ of POC concentration and $33 \% \pm 1 \%$ of the biosynthesis (OG/Mid May, Stn. \#8) before they dropped again in August, when N-limitation was strong at all stations.

$\mathrm{CH}$ distribution showed opposite trends with highest $\mathrm{CH}$ contributions in April $(79 \% \pm 6 \%$ of POC concentration, $92 \% \pm 2 \%$ of biosynthesis, OG, Stn. \#12), and lowest values in End May $(28 \% \pm 2 \%$ of POC concentration, $64 \% \pm 0 \%$ of biosynthesis, DB, Stn. \#8). The contribution of Glu and structural $\mathrm{CH}$ to the total $\mathrm{CH}$ pool showed large variations between stations and cruises. But Glu was the major sink for newly fixed $\mathrm{C}$ and contributed as much as $85 \% \pm 3 \%$ during strong nutrient limitation (OG/April, Stn. \#7) and as little as $37 \% \pm 10 \%$ in August (CNS, Stn. \#18) to biosynthesis. An exception was found at the CNS/April (Stn. \#16) when Cfixation into structural $\mathrm{CH}$ was much higher than that into Glu with $53 \% \pm 3 \%$ vs. $29 \% \pm 1 \%$, respectively. A more detailed phytoplankton analysis showed that Phaeocystis sp. contributed substantially to the community at this station (Burson et al. 2016). The extracellular matrix of Phaeocystis sp. colonies contains high amounts of structural $\mathrm{CH}$ that could explain the high concentrations encountered (Alderkamp et al. 2007).

Over the course of the year, FA concentrations increased, at the $\mathrm{CZ}$ and the OG all the way until August. At the DB 
and the CNS highest FA concentrations were reached in Mid May and decreased thereafter. Overall, FA contributed between $1 \% \pm 0 \%$ to $10 \% \pm 2 \%$ of POC concentration and $2 \% \pm 1 \%$ to $14 \% \pm 1 \%$ to biosynthesis at the different stations. Storage FA concentrations were higher than structural FA in the majority of stations and cruises in April and thereafter.

Biomolecule concentrations and synthesis were therefore mainly influenced by nutrient limitation and seasonal effects. Effects of phytoplankton community composition appeared to be less important (Fig. 9), although phytoplankton species can differ widely in their biomolecule composition (Becker 1994). Both diatom and flagellate dominated communities showed close correlation between the amount of AA in POC concentration and the amount synthesized. Notice however that AA synthesis reached zero at an AA content between $14 \%$ and $18 \%$ of POC concentration, suggesting a minimal AA content was needed to sustain algal cellular functions (Fig. 9a). Similar relationships between composition and synthesis were also observed for structural FA (Fig. 9b). However, the synthesis of structural $\mathrm{CH}$ differed between communities. While flagellates showed a close relationship between structural $\mathrm{CH}$ in POC concentration and their synthesis, the synthesis rates of structural $\mathrm{CH}$ in diatom-dominated communities were very low, even when concentrations were high (Fig. 9c). A possible explanation for this discrepancy may be the production of transparent exopolymer particles (TEP) in diatom-dominated communities. Due to the presence of a silicate shell, diatoms require no substantial amount of structural $\mathrm{CH}$ for cell-wall construction and may therefore release large amounts of dissolved $\mathrm{CH}$ into the surrounding seawater (Myklestad 2000), where they become part of the dissolved matter fraction that aggregates to TEP (Engel et al. 2012). If that was the case in our study, TEP would have contributed as extracellular POC to total POC pools. Previous research showed that ${ }^{13} \mathrm{C}$ labeled dissolved $\mathrm{CH}$ were detectable in the dissolved $\mathrm{C}$ pool after $14 \mathrm{~h}$ in cultures of Emiliania huxleyi (also containing an inorganic cell wall, Van Oostende et al. 2013). Our incubation times of $24 \mathrm{~h}$ may have been too short for the excretion of ${ }^{13} \mathrm{C}$-labeled $\mathrm{CH}$, the subsequent aggregation of TEP, and the consequent entrapment on the GF/F filters. To conclude, considering that diatoms possess an inorganic silicate shell and that structural $\mathrm{CH}$ synthesis rates were low, the high concentrations of structural $\mathrm{CH}$ detected in the $\mathrm{C}$ concentrations may have been predominantly derived from TEP.

\section{General discussion}

This study aimed to identify seasonal and spatial differences in phytoplankton responses to nutrient limitation patterns in the North Sea by looking at the incorporation of photosynthetically fixed ${ }^{13} \mathrm{C}$ into different biomolecule groups. It is the first study of its kind to address dynamics of such a wide range of compounds. We found that increase of
AA biosynthesis was a general response after the relief of nutrient limitation, both $\mathrm{N}$ - and P-limitation. However, the magnitude of response in P-limited communities was typically lower and seemed to be delayed compared to N-limited communities (Figs. 4, 6). This was most likely caused by required de novo synthesis of RNA and ribosomes, which are an important P-source and has to precede AA synthesis (Van Mooy and Devol 2008; Hessen et al. 2010). A new method was recently developed to trace ${ }^{13} \mathrm{C}$ into DNA and RNA nucleotides (Moerdijk-Poortvliet et al. 2014), and including it into future studies should be considered.

The biomolecule-bioassay approach identified the same nutrient limitation as the traditional bioassay (compare with Burson et al. 2016), demonstrating that quantifying AA biosynthesis in a classical bioassay set-up can be used on its own to identify the limiting nutrient in natural phytoplankton on shorter time-scales (within 24-72 h). Advantages over traditional bioassays are that these short incubation times limit bottle effects and avoid undesired changes within the phytoplankton community (Beardall et al. 2001). We compared the composition of structural FA in the different nutrient treatments after $24 \mathrm{~h}$ and $72 \mathrm{~h}$, and found that most stations (CZ/March, CZ and DB Mid May [Stns. \#1, 3, 13) showed relatively small shifts that were probably unrelated to the addition of nutrients and due to small differences in incubation settings, e.g., received light dosage or slightly warmer temperatures. However, in April both the $\mathrm{CZ}$ and the DB showed substantial shifts between the control incubations and the $+\mathrm{P} /+\mathrm{NPSi}$ and $+\mathrm{N} /+\mathrm{NPSi}$ treatments, respectively, indicating changes in their community structure (data not shown). While the community at the CZ (Stn. \#2) shifted from diatom-dominated towards a mixed community, the one at the DB (Stn. \#12) transitioned from a mixed into a more flagellate-dominated community. Although the current experimental set-up did not feature a complete factorial design, which made it difficult to clearly identify co-limitation and differentiate between types of colimitation (Harpole et al. 2011), the experimental set-up could easily be adapted to include more nutrient treatments at smaller sampling volumes to run AA-based bioassays.

The spatial limitation patterns agree with findings in other studies that identified the coastal areas of the North Sea and the adjacent Wadden Sea as mostly P-limited (Ly et al. 2014), while in areas farther offshore N-limitation persist throughout the growth season (Burson et al. 2016). A transitional zone around the OG switches from P- to N-limitation during the spring bloom depending on the position of the Frisian Front, which can migrate back and forth by $>100 \mathrm{~km}$, driven by weather conditions (Peeters and Peperzak 1990). During summer a shift to N-limitation can be observed in the CZ (Peeters and Peperzak 1990; Loebl et al. 2009; this study), which is probably controlled by a combination of seasonally changing DIN : DIP ratio in river water and regeneration of $\mathrm{P}$ from the sediment (Jensen et al. 
1995; Radach and Pätsch 2007), demonstrating the direct effect of changing nutrient loads in river water.

We found major variations in the biochemical composition in phytoplankton throughout the year (Fig. 8). The contribution of biomolecules to POC concentration and their biosynthesis in control incubations did not show clear enough patterns to identify the prevailing nutrient limitation $(\mathrm{N}, \mathrm{P}$, or $\mathrm{Si})$. But seasonal trends occurred such as low synthesis rates of AA were encountered in March when nutrient supply was sufficient but temperatures and light levels may have been below optimum. The accumulation of Glu and concurrent low levels of AA concentration and biosynthesis were identical to the response to nutrient limitation, concluding that it demonstrates a general stress response rather than a nutrient specific one (Figs. 6, 8). The synthesis of structural FA and Glu was not related (data not shown). Structural FA can derive from both phospho- and glycolipids. Although $\mathrm{P}$ is required in the synthesis of phospholipids, several phytoplankton are capable of substituting P- for $\mathrm{N}$ - or sulfur-containing polar head groups, guaranteeing synthesis of structural FA under P-limitation (Van Mooy et al. 2006). Furthermore, the concentrations of total FA encountered in this study were relatively low compared to culture studies where total FA can account $\geq 30 \%$ of biomass under nutrient limitation (Lynn et al. 2000; Mock and Kroon 2002).

Increased nutrient inputs into coastal seas like the North Sea led to eutrophication and increased biomass of primary producers. Based on the results of our bioassay, these primary producers should show increased biosynthesis rates of AA and probably structural FA, structural $\mathrm{CH}$ and RNA in order to keep growth rates high (Klausmeier et al. 2004; Arrigo 2005). As a consequence they would represented a high quality food source. Since the 1980s efforts have been taken throughout Europe to reduce riverine DIN and DIP inputs into coastal seas and decrease the effects of eutrophication (OSPAR 1988). However, efforts to decrease DIP were more successful than those for DIN, causing coastal DIN : DIP ratios to increase and led to an expansion of P-limited areas (Soetaert et al. 2006; Lenhart et al. 2010; Passy et al. 2013). At the same time Chl $a$ and POC biomass did not decrease as expected (McQuatters-Gollop et al. 2007b; Burson et al. 2016). But under increasing nutrient limiting conditions primary producers must have shifted towards the synthesis of C-rich storage biomolecules, which would have a negative impact on in their nutritional value.

According to the theory of ecological stoichiometry, the shifts between structural and storage compounds due to nutrient limitation leads to a specific response in the $\mathrm{C}: \mathrm{N}$ : $\mathrm{P}$ ratios in primary producers (Sterner and Elser 2002). These nutrient specific responses have been studied mainly in freshwater systems and demonstrate for instance that P-limitation in phytoplankton can lead to P-deficiencies in zooplankton causing lower performance (Boersma 2000; Elser et al. 2001). However, our results indicate that AA synthesis is generally affected by nutrient limitation and is also coupled to rRNA synthesis under P-limitation. In order to evaluate phytoplankton food quality, the biochemical composition may be a better predictor than the elemental composition, since growth and fitness of consumers respond strongly to specific molecules, (e.g., individual AA and FA; Müller-Navarra 1995). Only a few studies have focused on the effect of $\mathrm{C}: \mathrm{N}$ : P ratios in marine food webs (Walve and Larsson 1999; Malzahn et al. 2010; Schoo et al. 2010) and our study is one of the first in a coastal ecosystem to demonstrate the consequences of changing nutrient ratios to biomolecule composition of primary producers.

Our results could also be the foundation of explaining differences in trophic transfer efficiency and food chain length in other ecosystems. For example, oligotrophic parts of the ocean, which are primarily N-limited (Moore et al. 2013), will have decreased synthesis of N-containing biomolecules such as AA and RNA. At the same time storage compound contribution are probably high, providing limited essential AA and FA per unit biomass that may cause the low trophic transfer efficiencies encountered in these areas (Stibor and Sommer 2009). In contrast, nutrient enriched regions like upwelling areas where trophic transfer efficiencies and the availability of $\mathrm{N}$ and $\mathrm{P}$ are higher (Stibor and Sommer 2009) should show sufficient amounts of essential AA and FA in phytoplankton biomass. Increasing knowledge of dynamics of individual biomolecules and biomolecule groups (including DNA and RNA) would allow for a much more detailed view on phytoplankton food quality.

\section{References}

Alderkamp, A. C., A. G. J. Buma, and M. van Rijssel. 2007. The carbohydrates of Phaeocystis and their degradation in the microbial food web. Biogeochemistry 83: 99-118. doi: 10.1007/s10533-007-9078-2

Arrigo, K. R. 2005. Marine microorganisms and global nutrient cycles. Nature 437: 349-355. doi:10.1038/nature04159

Barnard, R., and others. 2004. Continuous plankton records: Plankton atlas of the North Atlantic Ocean (1958-1999). II. Biogeographical charts. Mar. Ecol. Prog. Ser. 11-75.

Beardall, J., E. Young, and S. Roberts. 2001. Approaches for determining phytoplankton nutrient limitation. Aquat. Sci. 63: 44-69. doi:10.1007/PL00001344

Becker, E. W. 1994. Chemical composition, p. 178. In J. Baddiley and others [eds.], Microalgae: Biotechnology and microbiology. Cambridge Univ. Press.

Bligh, E. G., and W. J. Dyer. 1959. A rapid method of total lipid extraction and purification. Can. J. Biochem. Physiol. 37: 911-917. doi:10.1139/o59-099

Boersma, M. 2000. The nutritional quality of P-limited algae for Daphnia. Limnol. Oceanogr. 45: 1157-1161. doi: 10.4319/lo.2000.45.5.1157

Bonnet, S., and others. 2008. Nutrient limitation of primary productivity in the Southeast Pacific (BIOSOPE cruise). Biogeosciences 5: 215-225. doi:10.5194/bg-5-215-2008 
Borsheim, K. Y., O. Vadstein, S. M. Myklestad, H. Reinertsen, S. Kirkvold, and Y. Olsen. 2005. Photosynthetic algal production, accumulation and release of phytoplankton storage carbohydrates and bacterial production in a gradient in daily nutrient supply. J. Plankton Res. 27: 743-755. doi:10.1093/plankt/fbi047

Boschker, H. 2004. Linking microbial community structure and functioning: Stable isotope $\left({ }^{13} \mathrm{C}\right)$ labeling in combination with PLFA analysis, p. 1673-1688. In G. A. Kowalchuk, F. J. de Bruijn, I. M. Head, A. D. Akkermans and J. D. van Elsas [eds.], Molecular microbial ecology manual II. Kluwer Academic.

Boschker, H. T. S., T. C. W. Moerdijk-Poortvliet, P. van Breugel, M. Houtekamer, and J. J. Middelburg. 2008. A versatile method for stable carbon isotope analysis of carbohydrates by high-performance liquid chromatography/ isotope ratio mass spectrometry. Rapid Commun. Mass Spectrom. 22: 3902-3908. doi:10.1002/rcm.3804

Burson, A., M. Stomp, L. Akil, C. P. D. Brussaard, and J. Huisman. 2016. Unbalanced reduction of nutrient loads has created an offshore gradient from phosphorus to nitrogen limitation in the North Sea. Limnol. Oceanogr. 61: 869-888. doi:10.1002/lno.10257

Cadée, G. C., and J. Hegeman. 2002. Phytoplankton in the Marsdiep at the end of the 20th century; 30 years monitoring biomass, primary production, and Phaeocystis blooms. J. Sea Res. 48: 97-110. doi:10.1016/S13851101(02)00161-2

Dalsgaard, J., M. St John, G. Kattner, D. Müller-Navarra, and W. Hagen. 2003. Fatty acid trophic markers in the pelagic marine environment. Adv. Mar. Biol. 46: 225-340. doi: 10.1016/s0065-2881(03)46005-7

Dijkman, N. A., and J. C. Kromkamp. 2006. Phospholipidderived fatty acids as chemotaxonomic markers for phytoplankton: Application for inferring phytoplankton composition. Mar. Ecol. Prog. Ser. 324: 113-125. doi:10.3354/ meps324113

Dortch, Q., T. L. Roberts, J. R. Clayton, and S. I. Ahmed. 1983. RNA: DNA ratios and DNA concentrations as indicators of growth-rate and biomass in planktonic marine organisms. Mar. Ecol. Prog. Ser. 13: 61-71. doi:10.3354/ meps013061

Dyhrman, S. T., and B. P. Palenik. 1997. The identification and purification of a cell-surface alkaline phosphatase from the dinoflagellate Prorocentrum minimum (Dinophyceae). J. Phycol. 33: 602-612. doi:10.1111/j.00223646.1997.00602.x

Elser, J. J., and others. 2000. Biological stoichiometry from genes to ecosystems. Ecol. Lett. 3: 540-550. doi:10.1046/ j.1461-0248.2000.00185.x

Elser, J. J., K. Hayakawa, and J. Urabe. 2001. Nutrient limitation reduces food quality for zooplankton: Daphnia response to seston phosphorus enrichment. Ecology 82: 898-903. doi:10.2307/2680208
Engel, A., J. Harlay, J. Piontek, and L. Chou. 2012. Contribution of combined carbohydrates to dissolved and particulate organic carbon after the spring bloom in the northern Bay of Biscay (North-Eastern Atlantic Ocean). Cont. Shelf Res. 45: 42-53. doi:10.1016/j.csr.2012.05.016

Falkowski, P. G. 2000. Rationalizing elemental ratios in unicellular algae. J. Phycol. 36: 3-6. doi:10.1046/j.15298817.2000.99161.x

Geider, R. J., and J. Laroche. 2002. Redfield revisited: Variability of C:N:P in marine microalgae and its biochemical basis. Eur. J. Phycol. 37: 1-17. doi:10.1017/ S0967026201003456

Goldman, J., and P. Glibert. 1983. Kinetics of inorganic nitrogen uptake by phytoplankton, p. 233-274. In E. J. Carpenter and D. G. Capone [eds.], Nitrogen in the marine environment. Academic Press.

González-Gil, S., B. A. Keafer, R. V. M. Jovine, A. Aguilera, S. $\mathrm{Lu}$, and D. M. Anderson. 1998. Detection and quantification of alkaline phosphatase in single cells of phosphorusstarved marine phytoplankton. Mar. Ecol. Prog. Ser. 164: 21-35. doi:10.3354/meps164021

Granum, E., S. Kirkvold, and S. M. Myklestad. 2002. Cellular and extracellular production of carbohydrates and amino acids by the marine diatom Skeletonema costatum: Diel variations and effects of $\mathrm{N}$ depletion. Mar. Ecol. Prog. Ser. 242: 83-94. doi:10.3354/meps242083

Grosse, J., P. van Breugel, and H. T. S. Boschker. 2015. Tracing carbon fixation in phytoplankton-compound specific and total ${ }^{13} \mathrm{C}$ incorporation rates. Limnol. Oceanogr.: Methods 13: 288-302. doi:10.1002/lom3.10025

Harpole, W. S., and others. 2011. Nutrient co-limitation of primary producer communities. Ecol. Lett. 14: 852-862. doi:10.1111/j.1461-0248.2011.01651.x

Hecky, R. E., and P. Kilham. 1988. Nutrient limitation of phytoplankton in fresh-water and marine environments - a review of recent evidence on the effects of enrichment. Limnol. Oceanogr. 33: 796-822. doi:10.4319/lo.1988.33.4part2.0796

Heinzelmann, S. M., N. J. Bale, E. C. Hopmans, J. S. S. Damste, S. Schouten, and M. T. van der Meer. 2014. Critical assessment of glyco- and phospholipid separation by using silica chromatography. Appl. Environ. Microbiol. 80: 360-365. doi:10.1128/AEM.02817-13

Hessen, D. O., P. D. Jeyasingh, M. Neiman, and L. J. Weider. 2010. Genome streamlining and the elemental costs of growth. Trends Ecol. Evol. 25: 75-80. doi:10.1016/ j.tree.2009.08.004

Howarth, R. W., and R. Marino. 2006. Nitrogen as the limiting nutrient for eutrophication in coastal marine ecosystems: Evolving views over three decades. Limnol. Oceanogr. 51: 364-376. doi:10.4319/1o.2006.51.1_part_2.0364

Jensen, H. S., P. B. Mortensen, F. Andersen, E. Rasmussen, and A. Jensen. 1995. Phosphorus cycling in a coastal marine sediment, Aarhus Bay, Denmark. Limnol. Oceanogr. 40: 908-917. doi:10.1038/nature02454 
Justic, D., N. N. Rabalais, and R. E. Turner. 1995. Stoichiometric nutrient balance and origin of coastal eutrophication. Mar. Pollut. Bull. 30: 41-46. doi:10.1016/0025326x(94)00105-i

Klausmeier, C. A., E. Litchman, T. Daufresne, and S. A. Levin. 2004. Optimal nitrogen-to-phosphorus stoichiometry of phytoplankton. Nature 429: 171-174. doi:10.1038/ nature 02454

Lancelot, C., N. Gypens, G. Billen, J. Garnier, and V. Roubeix. 2007. Testing an integrated river-ocean mathematical tool for linking marine eutrophication to land use: The Phaeocystis-dominated Belgian coastal zone (Southern North Sea) over the past 50 years. J. Mar. Syst. 64: 216-228. doi:10.1016/j.jmarsys.2006.03.010

Lenhart, H. J., and others. 2010. Predicting the consequences of nutrient reduction on the eutrophication status of the North Sea. J. Mar. Syst. 81: 148-170. doi:10.1016/ j.jmarsys.2009.12.014

Lindqvist, K., and R. Lignell. 1997. Intracellular partitioning of $\underline{14} \mathrm{CO}_{2}$ in phytoplankton during a growth season in the northern Baltic. Mar. Ecol. Prog. Ser. 152: 41-50. doi: 10.3354/meps152041

Loebl, M., F. Colijn, J. E. E. van Beusekom, J. G. Baretta-Bekker, C. Lancelot, C. J. M. Philippart, V. Rousseau, and K. H. Wiltshire. 2009. Recent patterns in potential phytoplankton limitation along the Northwest European continental coast. J. Sea Res. 61: 34-43. doi:10.1016/j.seares.2008.10.002

Ly, J., C. J. M. Philippart, and J. C. Kromkamp. 2014. Phosphorus limitation during a phytoplankton spring bloom in the western Dutch Wadden Sea. J. Sea Res. 88: 109120. doi:10.1016/j.seares.2013.12.010

Lynn, S. G., S. S. Kilham, D. A. Kreeger, and S. J. Interlandi. 2000. Effect of nutrient availability on the biochemical and elemental stoichiometry in the freshwater diatom Stephanodiscus minutulus (Bacillariophyceae). J. Phycol. 36: 510-522. doi:10.1046/j.1529-8817.2000.98251.x

Malzahn, A., F. Hantzsche, K. Schoo, M. Boersma, and N. Aberle. 2010. Differential effects of nutrient-limited primary production on primary, secondary or tertiary consumers. Oecologia 162: 35-48. doi:10.1007/s00442-009-1458-y

McCullagh, J. S. O., D. Juchelka, and R. E. M. Hedges. 2006. Analysis of amino acid ${ }^{13} \mathrm{C}$ abundance from human and faunal bone collagen using liquid chromatography/ isotope ratio mass spectrometry. Rapid Commun. Mass Spectrom. 20: 2761-2768. doi:10.1002/rcm.2651

McQuatters-Gollop, A., D. E. Raitsos, M. Edwards, and M. J. Attrill. 2007a. Spatial patterns of diatom and dinoflagellate seasonal cycles in the NE Atlantic Ocean. Mar. Ecol. Prog. Ser. 339: 301-306. doi:10.3354/meps339301

McQuatters-Gollop, A., D. E. Raitsos, M. Edwards, Y. Pradhan, L. D. Mee, S. J. Lavender, and M. J. Attrill. 2007b. A long-term chlorophyll data set reveals regime shift in North Sea phytoplankton biomass unconnected to nutrient trends. Limnol. Oceanogr. 52: 635-648. doi:10.4319/lo.2007.52.2.0635
Mills, M. M., C. Ridame, M. Davey, J. La Roche, and R. J. Geider. 2004. Iron and phosphorus co-limit nitrogen fixation in the eastern tropical North Atlantic. Nature 429: 292-294. doi:10.1038/nature02550

Mock, T., and B. M. A. Kroon. 2002. Photosynthetic energy conversion under extreme conditions - I: Important role of lipids as structural modulators and energy sink under N-limited growth in Antarctic sea ice diatoms. Phytochemistry 61: 41-51. doi:10.1016/S0031-9422(02)00216-9

Moerdijk-Poortvliet, T. C. W., J. Brasser, G. de Ruiter, M. Houtekamer, H. Bolhuis, L. J. Stal, and H. T. S. Boschker. 2014. A versatile method for simultaneous stable carbon isotope analysis of DNA and RNA nucleotides by liquid chromatography/isotope ratio mass spectrometry. Rapid Commun. Mass Spectrom. 28: 1401-1411. doi:10.1002/rcm.6919

Moisander, P. H., R. Zhang, E. A. Boyle, I. Hewson, J. P. Montoya, and J. P. Zehr. 2012. Analogous nutrient limitations in unicellular diazotrophs and Prochlorococcus in the South Pacific Ocean. ISME J. 6: 733-744. doi:10.1038/ ismej.2011.152

Moore, C. M., and others. 2013. Processes and patterns of oceanic nutrient limitation. Nat. Geosci. 6: 701-710. doi: 10.1038/ngeo1765

Müller-Navarra, D. 1995. Evidence that a highly unsaturated fatty-acid limits Daphnia growth in nature. Arch. Hydrobiol. 132: 297-307.

Myklestad, S. 2000. Dissolved organic carbon from phytoplankton, p. 111-148. In P. J. Wangersky [ed.], Marine chemistry. Springer Berlin Heidelberg.

OSPAR. 1988. PARCOM recommendation 88/2: On the reduction in nutrients to the Paris convention area. Publication number 88/2, Paris Commission.

Passy, P., and others. 2013. A model reconstruction of riverine nutrient fluxes and eutrophication in the Belgian Coastal Zone since 1984. J. Mar. Syst. 128: 106-122. doi: 10.1016/j.jmarsys.2013.05.005

Peeters, J. C. H., and L. Peperzak. 1990. Nutrient limitation in the North Sea - a bioassay approach. Neth. J. Sea Res. 26: 61-73. doi:10.1016/0077-7579(90)90056-M

Philippart, C. J. M., G. C. Cadee, W. van Raaphorst, and R. Riegman. 2000. Long-term phytoplankton-nutrient interactions in a shallow coastal sea: Algal community structure, nutrient budgets, and denitrification potential. Limnol. Oceanogr. 45: 131-144. doi:10.4319/lo.2000.45.1. 0131

Philippart, C. J. M., J. J. Beukema, G. C. Cadee, R. Dekker, P. W. Goedhart, J. M. van Iperen, M. F. Leopold, and P. M. J. Herman. 2007. Impacts of nutrient reduction on coastal communities. Ecosystems 10: 95-118. doi:10.1007/ s10021-006-9006-7

Plath, K., and M. Boersma. 2001. Mineral limitation of zooplankton: Stoichiometric constraints and optimal foraging. Ecology. 82: 1260-1269. doi: 10.1890/0012-9658 (2001)082[1260:mlozsc]2.0.co;2 
Quigg, A., and others. 2003. The evolutionary inheritance of elemental stoichiometry in marine phytoplankton. Nature 425: 291-294. doi:10.1038/nature01953

Radach, G., and J. Pätsch. 2007. Variability of continental riverine freshwater and nutrient inputs into the North Sea for the years 1977-2000 and its consequences for the assessment of eutrophication. Estuar. Coast. 30: 66-81. doi:10.1007/BF02782968

Redfield, A. C., B. A. Ketchum, and F. A. Richards. 1963. The influence of organisms on the composition of sea-water, p. 26-77. In M. N. Hill [ed.], The sea. John Wiley.

Riegman, R., A. M. Noordeloos, and G. Cadée. 1992. Phaeocystis blooms and eutrophication of the continental coastal zones of the North Sea. Mar. Biol. 112: 479-484. doi: 10.1007/BF00356293

Schoo, K., N. Aberle, A. Malzahn, and M. Boersma. 2010. Does the nutrient stoichiometry of primary producers affect the secondary consumer Pleurobrachia pileus? Aquat, Ecol. 44: 233-242. doi:10.1007/s10452-009-9265-4

Soetaert, K., J. J. Middelburg, C. Heip, P. Meire, S. Van Damme, and T. Maris. 2006. Long-term change in dissolved inorganic nutrients in the heterotrophic Scheldt estuary (Belgium, The Netherlands). Limnol. Oceanogr. 51: 409-423. doi:10.4319/lo.2006.51.1_part_2.0409

Sterner, R. W., D. D. Hagemeier, W. L. Smith, and R. F. Smith. 1993. Phytoplankton nutrient limitation and food quality in Daphnia. Limnol. Oceanogr. 38: 857-871. doi: 10.4319/lo.1993.38.4.0857

Sterner, R. W., and J. J. Elser. 2002. Ecological stoichiometry: The biology of elements from molecules to the biosphere. Princeton Univ. Press.

Stibor, H., and U. Sommer. 2009. Ocean food webs and trophic, p. 96-113. In C. M. Duarte and A. L. Helgueras [eds.], Marine ecology, developed under the auspices of the UNESCO. Eolss Publishers. Available from http:// www.eolss.net

Suárez, I., and E. Marañón. 2003. Photosynthate allocation in a temperate sea over an annual cycle: The relationship between protein synthesis and phytoplankton physiological state. J. Sea Res. 50: 285-299. doi:10.1016/ j.seares.2003.04.002

Tilman, D., and S. S. Kilham. 1976. Phosphate and silicate growth and uptake kinetics of the diatoms Asterionelle formosa and Cyclotella meneghiniana in batch and semicontinious culture. J. Phycol. 12: 375-383. doi:10.1111/ j.1529-8817.1976.tb02860.x

Turner, R. E., N. N. Rabalais, D. Justic, and Q. Dortch. 2003. Global patterns of dissolved N, P and Si in large rivers. Biogeochemistry 64: 297-317. doi:10.1023/A:1024960007569

Van Beusekom, J. E. E., and S. Diel-Christiansen. 2009. Global change and the biogeochemistry of the North Sea: The possible role of phytoplankton and phytoplankton grazing. Int. J. Earth Sci. 98: 269-280. doi:10.1007/s00531-007-0233-8
Van Haren, H., D. K. Mills, and L. P. M. J. Wetsteyn. 1998. Detailed observations of the phytoplankton spring bloom in the stratifying central North Sea. J. Mar. Res. 56: 655680. doi:10.1357/002224098765213621

Van Mooy, B. A. S., G. Rocap, H. F. Fredricks, C. T. Evans, and A. H. Devol. 2006. Sulfolipids dramatically decrease phosphorus demand by picocyanobacteria in oligotrophic marine environments. Proc. Natl. Acad. Sci. USA 103: 8607-8612. doi:10.1073/pnas.0600540103

Van Mooy, B. A. S., and A. H. Devol. 2008. Assessing nutrient limitation of Prochlorococcus in the North Pacific subtropical gyre by using an RNA capture method. Limnol. Oceanogr. 53: 78-88. doi:10.4319/lo.2008.53.1.0078

Van Oostende, N., T. C. W. Moerdijk-Poortvliet, H. T. S. Boschker, W. Vyverman, and K. Sabbe. 2013. Release of dissolved carbohydrates by Emiliania huxleyi and formation of transparent exopolymer particles depend on algal life cycle and bacterial activity. Environ. Microbiol. 15: 1514-1531. doi:10.1111/j.1462-2920.2012.02873.x

Walve, J., and U. Larsson. 1999. Carbon, nitrogen and phosphorus stoichiometry of crustacean zooplankton in the Baltic Sea: Implications for nutrient recycling. J. Plankton Res. 21: 2309-2321. doi:10.1093/plankt/21.12.2309

Wang, X., B. Huang, and H. Zhang. 2014. Phosphorus deficiency affects multiple macromolecular biosynthesis pathways of Thalassiosira weissflogii. Acta Oceanolog Sin. 33: 85-91. doi:10.1007/s13131-014-0413-X

Weston, K., L. Fernand, D. K. Mills, R. Delahunty, and J. Brown. 2005. Primary production in the deep chlorophyll maximum of the central North Sea. J. Plankton Res. 27: 909-922. doi:10.1093/plankt/fbi064

Wright, S. W., and S. W. Jeffrey. 2006. Pigment markers for phytoplankton production, p. 71-104. In J. K. Volkman [ed.], Marine organic matter: Biomarkers, isotopes and DNA. Springer Berlin Heidelberg.

\section{Acknowledgments}

The authors thank the Captains and crew of the R/V Pelagia for their help and support during the cruises, and Amanda Burson, Ruben van Drie and Elodie Burrillon for their skilled assistance with experimental work onboard. Special thanks to the Nutrient Lab at NIOZ-Texel for providing nutrient data and the Analytical Lab at NIOZ-Yerseke for the analysis of pigment samples. This research is part of the CHARLET project and was supported by the Netherlands Organization for Scientific Research (NWO) to HTSB (grant ZKO 839.10.511).

\section{Conflict of Interest}

None declared.

Submitted 12 March 2016

Revised 04 August 2016

Accepted 12 August 2016

Associate editor: Ronnie Glud 